\title{
9. EARLY CRETACEOUS PLANKTONIC FORAMINIFERS FROM EASTERN NORTH ATLANTIC, DSDP LEG 41
}

\author{
Uwe Pflaumann, Geological-Paleontological Institute, Kiel University, Federal Republic of Germany \\ and \\ Valery A. Krasheninnikov, Geological Institute of the USSR Academy of Sciences, Moscow, USSR
}

\begin{abstract}
Early Cretaceous (including the early Cenomanian) sediments were recovered at four sites. Age determinations by the planktonic foraminifers are controlled by the nannofossil record.

At Site 367 (Cape Verde Basin), planktonic foraminifers occur only in variegated claystones and black shales of late Aptian to Cenomanian age. Low species diversity, small individual growth, scattered occurrences, and ${ }^{\circ}$ the absence of keeled forms in the higher cores point to a special paleoenvironment.

At Site 368 (Cape Verde Rise) black shales with rare occurrences of tiny, poorly preserved planktonic foraminifers of AlbianTuronian age were recovered. Coring ceased within this facies.

Site 369 (continental slope off Spanish Sahara), olive-black nannofossil marls, containing partly rich and well-preserved planktonic foraminifers of Aptian and Albian age, were recovered. The Tethyan zonation by planktonic foraminifers could be used, and nearly all zones recorded. Nearly continuous high abundances of planktonic foraminifers point to a paleoenvironment on a quiet slope with accumulation rates lower than today.

At Site 370 (deep basin off Morocco) Paleogene sediments overlie nanno-bearing claystones with numerous well-preserved planktonic foraminifers of uppermost Albian and early Cenomanian age, and dark silty claystones and coarse-grained sediments with only reduced amounts of planktonic foraminifers of Hauterivian to early Albian age. The lower section is influenced by mainly terrigenous input, while during the Albian a revolution in paleoenvironmental conditions is indicated by high productivity of the surface water masses and an invasion of a normal ${ }^{\circ}$ Tethys fauna.

Biostratigraphical correlations of Leg 41 holes yielded the separation of 15 time intervals between late Hauterivian and early Cenomanian. In summarizing the results of previous DSDP sites the Early Cretaceous paleogeography of the North Atlantic has to be reconstructed within three main sections: earliest Cretaceous to Valanginian with no planktonic foraminifers, Hauterivian to Albian with scattered and poor record, and Albian to Cenomanian with rich record of planktonic foraminifers. With the planktonic foraminifers we may assume, that during Hauterivian-Albian the North Atlantic had been a relatively small sea, adjacent to the Tethys, divided by the mid-oceanic ridge or ridges into several basins.

Planktonic foraminifer fauna is influenced by separation, isolation, and/or dissolution. The Albian/Cenomanian time had open ocean conditions with good faunal exchange to the Tethys, which may be due to a generally higher sea level or due to a subsidence of the ocean floor, while black shale conditions continue in some regions.
\end{abstract}

\section{INTRODUCTION}

Early Cretaceous sediments have been drilled and cored at four sites (Figure 1). Age determinations were made using the fossil record, with the help of foraminifers and nannofossils. However this record is rather discontinuous, partly due to poor preservation or absence of calcareous fossils in the sediments. However, the cooperation between foraminifer and nannofossil-stratigraphers enabled the solution of the presence/absence problem of index fossils within either group.

Planktonic foraminifers have been separated in Early Cretaceous sediments in Sites 367,368, 369A, and 370. 


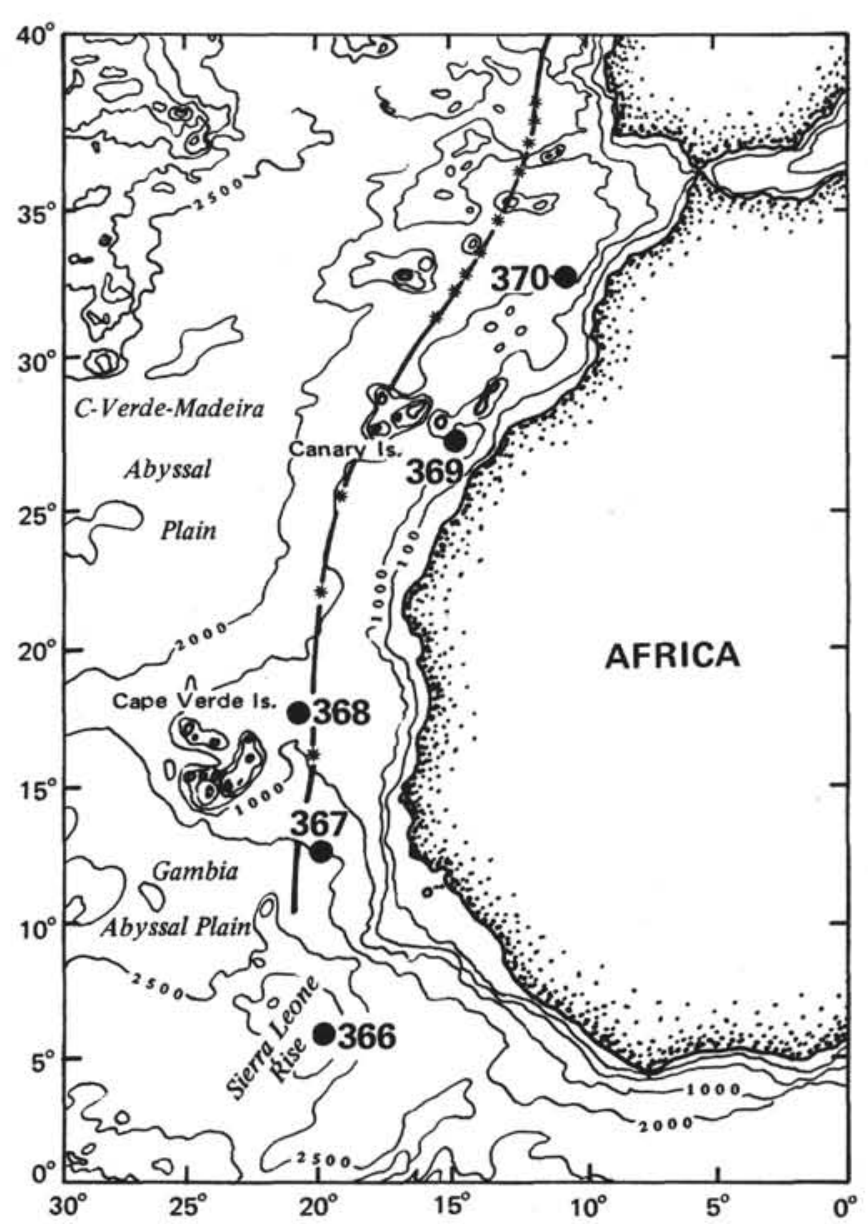

Figure 1. Location of Leg 41 Sites 367, 368, 369, 370.

The last two sites have faunas of Aptian-Albian age, which can easily be classified with the classical zonation scheme. Sites 367 and 368 produced only poor records with reduced species diversity and specimen growth, so that the stratigraphic determination is within wider limits.

\section{REGIONAL STRATIGRAPHY}

An overview of the main data of the holes, in which Early Cretaceous (including Cenomanian) sediments have been recovered, is presented in Table 1.

\section{Cape Verde Basin}

Site 367 penetrated Early Cretaceous sediments below an Upper Cretaceous section of multicolored silty clays and above light gray nanno-limestones, interbedded with olive-gray marlstones, black shale, and rare chert of Late Jurassic age. The Early Cretaceous

TABLE 1

Data on the Holes of Leg 41 With Early Cretaceous Recovery

\begin{tabular}{|c|c|c|c|c|c|}
\hline Hole & $\begin{array}{l}\text { Latitude } \\
(\mathrm{N})\end{array}$ & $\begin{array}{l}\text { Longitude } \\
\text { (W) }\end{array}$ & $\begin{array}{l}\text { Water } \\
\text { Depth } \\
(\mathrm{m})\end{array}$ & $\begin{array}{l}\text { Thickness of } \\
\text { Drilled Early } \\
\text { Cretaceous } \\
\text { Sediments } \\
\text { (incl. } \\
\text { Cenomanian) }\end{array}$ & $\begin{array}{c}\text { Number of Cores } \\
\text { in Early } \\
\text { Cretaceous } \\
\text { Sediments } \\
\text { (incl. Cenomanian) }\end{array}$ \\
\hline $\begin{array}{l}367 \\
368 \\
369 A \\
370\end{array}$ & $\begin{array}{l}12^{\circ} 29^{\prime} 21^{\prime \prime} \\
17^{\circ} 30^{\prime} 43^{\prime \prime} \\
26^{\circ} 35^{\prime} 55^{\prime \prime} \\
32^{\circ} 50^{\prime} 25^{\prime \prime}\end{array}$ & $\begin{array}{l}20^{\circ} 02^{\prime} 83^{\prime \prime} \\
21^{\circ} 21^{\prime} 23^{\prime \prime} \\
14^{\circ} 59^{\prime} 96^{\prime \prime} \\
10^{\circ} 46^{\prime} 56^{\prime \prime}\end{array}$ & $\begin{array}{l}4748 \\
3367 \\
1760 \\
4216\end{array}$ & $\begin{array}{r}368.5 \\
\text { ca. } 16.0 \\
66.5 \\
513.0\end{array}$ & $\begin{array}{r}12 \\
2 \\
7 \\
32\end{array}$ \\
\hline
\end{tabular}

section has been divided into three lithologic units: black shale; variegated claystone; light gray limestone interbedded with olive-gray marlstone, black shale, and rare chert.

Planktonic foraminifers have been encountered only in the upper two lithologic units, displaying a scattered occurrence of various preservations ranging from excellent to very poor. Abundances range between abundant and none in the black shales of Albian to Cenomanian age and are high in few samples of the dark interbeds of the variegated Aptian claystones.

The benthic foraminifer fauna is rare in the black shales; only fish remains are common. In the Aptian, the planktonic foraminifers are associated with agglutinated foraminifers and some lagenids. The individual sizes of the planktonic foraminifers are generally very small, often below $125 \mu \mathrm{m}$ in diameter.

Guembelitria harrisi, Heterohelix moremani, and Hedbergella brittonensis place the samples of Core 19 to Core 21, Section 6 in the Cenomanian. Keeled rotaliporas are missing. Thickness is 55 meters.

Samples 21, CC to 22, CC are Albian, as they contain Ticinella primula and Ticinella raynaudi. Core 23 is barren of foraminifers. Sample 24, CC contains Gubkinella graysonensis, ${ }^{\circ}$ Hedbergella infracretacea, Hedbergella aff. planispira, Hedbergella globigerinellinoides, Hedbergella aff. kugleri, Globigerinelloides aptiensis. The range of this faunula would be Barremian to Aptian. Nannofossil determination (Cepek, this volume) in Core 25 shows the Parhabdolithus angustus Zone, so the age can be restricted to late Aptian.

The foraminifer fauna of the Early Cretaceous is characterized by low species diversity, small individuals, scattered occurrence of planktonics with sudden high planktonic abundance, and excellent preservation with reduced benthic species diversity.

Low species diversity points to unfavorable living conditions such as abnormally low or high salinity or temperature. Stunted individual growth may be caused by the same circumstances. Scattered occurrences might be explained by changing effectiveness of dissolution. Calcareous fossil preservation may be enhanced due to raised productivity, or higher accumulation rates of embedding sediment. If low abundances normally result from isolation, faunal invasions in water masses which sporadically overcome a normally closed barrier will increase abundance. Reduced benthic diversity is normally a signal of deficient nutrients, often in combination with great water depths.

Excellent preservation occurs from reduced dissolution in combination with rapid sedimentation, low influence of bottom currents, low reworking by burrowing organisms, and buffered $p \mathrm{H}$ values of the sediment interstitial water.

Black shale facies may form under several conditions and the foraminifer content points to the following implications:

Phase I: Jurassic to earliest Cretaceous: Planktonic foraminifers are missing. Benthic foraminifers in the Jurassic point to far offshore, pelagic conditions. Depth was greater than the CCD.

Intercalations of marlstones and black shales with poor, scattered fauna may be interpreted by "isolated 
basin effects." Raised carbonate contents may be caused by elevated nanno-productivity and/or reduced dissolution,

Phase II: Middle part of Early Cretaceous: Planktonic foraminifers are evolving. Their species production centers are in the favored "Tethys-regions."

The site only sporadically shows the history of planktonic foraminifers. This may occur because the isolated basin had reduced exchange of surface water masses.

\section{Cape Verde Rise}

Site 368 sediments consist of black shales with abundant fish debris, pyritic casts of radiolarians and diatoms, and sporadic agglutinated foraminifers. Planktonic foraminifers occur only in very thin, slightly calcareous sediment layers. The fauna is small sized and poorly preserved. The presence of Hedbergella delrioensis, Hedbergella planispira, Hedbergella simplicissima, together with Heterohelix sp. sp. and Guembelitria sp. allows its classification in the Albian-Turonian time interval. Samples 368-62-4 and 63, CC were the last recovered at this site, so the underlying formations remain unknown.

\section{Continental Slope off Spanish Sahara}

Hole 369A reaches Early Cretaceous olive-black silty nannofossil marls, about 66.5 meters in thickness, which contain partly rich and well-preserved planktonic foraminifers of an Aptian to Albian age. Though coring was continuous, the recovery was generally between $43 \%$ and $74 \%$. Therefore, all of the planktonic foraminifer zones of this time interval probably have not recovered due to the rapid evolution during Albian time.

Sections 369A-41-3 to 42-3 contain the zonal fossil Rotalipora ticinensis, which is attributed to the uppermost Albian stage Vraconian. However in Section 41-4 some Upper Cretaceous globotruncanas were encountered, which point to a redeposition of the Albian sediments. Slumps occur in Sections 41-1 and 2. An additional slump may occur in Section $41-1$, or Sample $41-4,73-75 \mathrm{~cm}$ is contaminated.

The fauna is marked by the index species together with Rotalipora subticinensis, Ticinella raynaudi, Ticinella roberti, Ticinella primula, Globigerinelloides breggiensis, Globigerinelloides caseyi, Globigerinelloides bentonensis, Globigerinelloides portsdownensis, Clavihedbergella moremani, Hedbergella simplicissima, Schackoina cenomana, Praeglobotruncana delrioensis, Hedbergella delrioensis, Hedbergella planispira, Hedbergella aff. simplex. The benthic foraminifers are represented by some lenticulinas.

Sample 369A-42, CC, is characterized by Rotalipora subticinensis, Ticinella roberti, Ticinella bejaouaensis, Clavihedbergella simplex, Globigerinelloides breggiensis, Globigerinelloides ferreolensis, Hedbergella trocoidea, Hedbergella infracretacea, Hedbergella globigerinellinoides, Hedbergella simplicissima. This fauna is attributed to late Albian, just below the base of the Rotalipora ticinensis Zone.

The section between Sections 43-1 and 43-4 contains the species Ticinella praeticinensis, Ticinella raynaudi raynaudi, Ticinella raynaudi digitalis, Ticinella raynaudi aperta, Ticinella primula, Praeglobotruncana aff. $^{\circ}$ delrioensis, Hedbergella simplicissima, Hedbergella planispira, Hedbergella delrioensis, Hedbergella aff. subcretacea. Ticinella praeticinensis is most common in middle Albian (Sigal, 1966), Ticinella raynaudi and its subspecies start in the late Albian, so this section should be attributed to middle and late Albian. The nannofossil zonation gives a Prediscosphaera cretacea age, restricting the age to middle Albian, (Ticinella praeticinensis Zone).

Sample 43, CC and Section 44-1 are attributed to the Ticinella roberti Zone with the index fossil, Ticinella aff. primula, Ticinella bejaouaensis, Ticinella transitoria, Hedbergella simplex, Hedbergella planspira, Hedbergella trocoidea, Hedbergella infracretacea, Ticinella aff. breggiensis. According to Sigal (1966) the cooccurrence of Ticinella roberti and the first intergrades to Ticinella primula and Ticinella breggiensis suggests an early Albian age for this section.

Section $44-2$ is exceptionally poor in faunal content. Sections $44-3$ and $44, C C$ are characterized by the first occurrence of Ticinella with Ticinella bejaouaensis, Ticinella transitoria, Ticinella aff. roberti, Hedbergella trocoidea, Hedbergella infracretacea, Hedbergella planispira, Hedbergella delrioensis, Hedbergella globigerinellinoides, Hedbergella aff. simplicissima, Hedbergella aff. simplex, "Globigerinelloides" cf. breggiensis, and the last occurrence of Globigerinelloides ferreolensis. The nannofossil record gives the Prediscosphaera cretacea Zone. We attribute this section to Ticinella bejaouaensis Zone (Longoria, 1974), uppermost Aptian (Clansayesian). Some lagenids and tiny buliminids are the main accompanying benthic components in this and the former sections.

All the samples of Core 45 contain no Ticinella. Their nannofossil age is given as the Parhabdolithus angustus Zone. The planktonic foraminifers are represented by the genera Hedbergella and Globigerinelloides, as Hedbergella planispira, Hedbergella delrioensis, Hedbergella infracretacea, Hedbergella trocoidea, Hedbergella aff. simplicissima, Hedbergella aff. simplex, Hedbergella aff. subcretacea, and Globigerinelloides ferreolensis and "Globigerinelloides" breggiensis. The abundance is high, preservation excellent, and the individual growth tends to small forms. Benthic foraminifera are few: lagenidae, Marssonella, Gavelinella. The age is given as undifferentiated late Aptian.

Sections $46-2$ to $46-4$ are characterized by the cooccurrence of Hedbergella sigali and Globigerinelloides ferreolensis besides aforementioned species of the prior section. According to Longoria (1974) this cooccurrence is given in the early Gargasian, named Leupoldina cabri Zone.

The section between Sections 46-5 and 47-5 contains the same species except for Globigerinelloides ferreolensis, Hedbergella similis, and Loeblichella aff. convexa. After Longoria (1974) this fauna should be dated as early Leupoldina cabri Zone. However, additional studies of these faunas are necessary to confirm this dating. Among the benthic components encountered are some more agglutinated foraminifers, lagenids, rotalids, molluscan, and echinoderm fragments. 
The lowermost sample of the site, 47, CC, contains Globigerinelloides gottisi, Globigerinelloides blowi, Globigerinelloides ultramicrus, Hedbergella infracretacea, Hedbergella globigerinellinoides, Hedbergella aff. simplicissima, Hedbergella aff. simplex. Its age may be early Aptian, though by the nannofossil record the Chiastozygus litterarius Zone could not be established.

In summary the section of Early Cretaceous sediments at Site 369A shows a useful evolution of planktonic foraminifers. Nearly all published zones could be determined in the standard sampling for this initial report. Additional samples may fill gaps and further studies will help to clarify the Aptian-Albian foraminiferal zonation scheme.

The environmental conditions are indicated by nearly continuous high abundances of planktonic foraminifers, a very low benthos-plankton ratio, excellent preservation, and a low amount of terrigenous components in the coarse fraction.

The present location of the site is on a continental slope and the location also may have been a slope during Early Cretaceous time, continuous section does not suggest major slope activities. Accumulation rates of about $5 \mathrm{~m} / \mathrm{m} . \mathrm{y}$. are distinctly lower than modern ones, indicating reduced terrigenous input in the past. The reduction of the accumulation rates is hardly to explain by continuous minislumping, and erosion.

The normal growth of planktonic foraminifers points to a good connection with the Tethyan province in addition to evolutionary trends. Partly excellent preservation of calcareous remains suggests a water depth well above the CCD.

\section{Deep Basin off Morocco}

The Early Cretaceous section of Site 370 is composed of a layer of nanno-bearing claystones grading into claystones in the upper part and dark calcareous silty claystones, nanno-bearing claystones interbedded with greenish siltstones, and gravelly claystones and conglomerates in the lower part. The upper part, about 55 meters thick was cored continuously, and the recovery was between $22 \%$ and $68 \%$. Foraminifer and nannofossil age determinations suggest that the section belongs to the late Albian/Cenomanian. It is overlain by Paleogene sediments, but the contact is in a 9.5meter uncored interval.

The lower part of the Early Cretaceous section, also cored continuously, had reduced recoveries, down to $2 \%$. Recovered planktonic foraminifers were numerous, well preserved, and of normal size in the calcareous clays of the higher section (Cores 20 to 24). The mostly silty sediments and dark shales of the lower section rarely contain considerable amounts of planktonic foraminifers which are of medium to poor preservation.

The following biostratigraphic sections have been encountered by the microfossil content at Site 370:

Cores 20 to 24 contain well-preserved Rotalipora apenninica, Praeglobotruncana delrioensis, Schackoina cenomana, Hedbergella delrioensis, Hedbergella planispira, Hedbergella infracretacea, Hedbergella simplicissima, Hedbergella simplex, Globigerinelloides bentonensis, Globigerinelloides caseyi, Heterohelix sp. sp. and are attributed to uppermost Albian and early
Cenomanian age, the Rotalipora apenninica Zone. Thickness is 47.5 meters.

Cores 25 and 26 provide planktonic foraminifer faunas of partly reduced diversity and quantity. This section contains Praeglobotruncana delrioensis, Schackoina cenomana, Globigerinelloides caseyi, Globigerinelloides aff. bentonensis, Hedbergella simplicissima, Hedbergella globigerinellinoides, Hedbergella delrioensis and Heterohelix sp. The absence of Rotalipora or Ticinella prevents a direct zonal determination. Comparison to the results of Hole 369A enables assignment of this fauna to the Rotalipora ticinensis Zone (Vraconian, uppermost Albian).

The benthic foraminifer fauna is quite diverse and contains primitive agglutinated species as well as spiroplectamminids, miliolids, lagenids, and gavelinellas. Fish debris, echinoderm fragments, and sponge spicules are often recorded. Calcisphaerulids are restricted to the Rotalipora apenninica Zone.

The samples of Core 27 are barren of planktonic foraminifers. In Cores 28 and 29 only poorly preserved tiny planktonic foraminifers occur (Hedbergella globigerinellinoides, Hedbergella trocoidea, Hedbergella infracretacea, and Hedbergella delrioensis). The age of this fauna is in the range of late Aptian-Albian, the nannofossil record, Parhabdolithus angustus Zone, confirms the precision of the results. The faunal content of the underlying sections restricts the interval to Albian age.

Sections 30-4 and 30, CC, contain a tiny faunula of Hedbergella sigali, Hedbergella delrioensis, Hedbergella infracretacea, Hedbergella gorbatchikae, Globigerinelloides aff. gottisi, Gubkinella graysonensis and "Globigerinelloides" gyroidinaeformis, the latter of nearly normal size. The youngest elements of this fauna give an age of early Albian, the Ticinella bejaouaensis "Globigerinelloides" gyroidinaeformis Zone (van Hinte, 1975).

There is no record of planktonic foraminifers in the samples from Cores 31 and 32. These samples, and those up through Core 27, contain primitive agglutinated foraminifers and fish remains.

Core 34 has a nannofossil age of Barremian. It contains a tiny but relatively diverse planktonic fauna: Hedbergella sigali, Hedbergella planispira, Hedbergella delrioensis, Hedbergella aff. gorbatchikae, Hedbergella aff. infracretacea, Globigerinelloides aptiense, Globigerinelloides ultramicrus, Globigerinelloides gottisi, Gubkinella graysonensis, and Loeblichella moulladei. The benthic component of the foraminiferal fauna contains calcareous forms: Lagenids, Gyroidina, Cibicides, and spirillinids.

The nanno-age determination for Cores 35 to 37 is no younger than late Hauterivian. The planktonic fauna contains nearly the same species. Hedbergella aff. gorbatchikae, Hedbergella globigerinellinoides, Loeblichella sp. are missing, while Caucasella hoterivica, Hedbergella occulta, Hedbergella aff. similis, and Hedbergella aff. sigali are added. The benthic foraminifer fauna is similar to the previous interval. Sample 37, CC, is the oldest sample in the Early Cretaceous section which contains planktonic foraminifers. 
The planktonic foraminifer record of the Early Cretaceous of Site 370 shows the early evolution of the planktonic foraminifers. However, the poor preservation and scattered occurrences in the sediments below late Albian require additional investigations, especially in the Hauterivian to Aptian sections.

Abundance and preservation of planktonic foraminifers allow the Early Cretaceous to be divided into a lower, Hauterivian to early Albian section with scattered occurrences and almost poor preservation, and a late Albian/Cenomanian part with excellent preservation and high abundances. In the coarse fraction, the lower part is influenced mainly by terrigenous input, while in the higher part biogenous production is dominant. Abundance and composition of benthic fauna point to deep-sea conditions with strong dissolution effects. The interesting, but in general sporadic, plankton pulses may be caused by changes of water masses, which lower the CCD as well as change the fertility of the surface waters during Hauterivian to Aptian times.

During the late Albian a change in environmental conditions occurred. High productivity of the surface waters, a lowered CCD, and a "normal" Tethyan faunal invasion occurred. The reduced terrigenous influence suggests changes of climate on land or the existence of barriers which prevented the input of terrigenous material. The possibility of strong currents between the site and the slope, minimizing terrestrial supply, cannot be excluded.

\section{BIOSTRATIGRAPHIC CORRELATION OF LEG 41 HOLES}

Using the age determinations from planktonic foraminifers and nannofossils, many zones and sections have been recognized in the Early Cretaceous off West Africa. The result is shown in Figure 2, using the shipboard scientists' results, literature data, and a manuscript chart of van Hinte for the main zonal and age intercorrelations.

1) Cenomanian, dated by Guembelitria harrisi, Heterohelix moremani, and Hedbergella brittonensis. Site 367 , Cores 19 to 21 , Section 6 .

2) Rotalipora apenninica Zone, late Vraconian to early Cenomanian. Sites 370 , Cores 20 to 24 .

3a) Vraconian, dated by Schackoina cenomana, Globigerinelloides caseyi, Globigerinelloides bentonensis, and heterohelicids below the first occurrence of Rotalipora apenninica. Site 370, Cores 25 and 26.

3b) Rotalipora ticinensis Zone, Vraconian, dated by the presence of Rotalipora ticinensis. Site 369A, Samples 41, CC, to $42-3$.

4) Rotalipora subticinensis Zone, late Albian, dated by the presence of Rotalipora subticinensis before the first occurrence of Rotalipora ticinensis. Site 369A, Sample 42, CC.

5) Albian, dated by nannofossils as Prediscosphaera cretacea Zone and by foraminifers as Ticinella praeticinensis Zone. Site 369A, Sections 41-1 to 43-4.

6) Albian, dated by nannofossils as Predicosphaera cretacea Zone and by foraminifers as Ticinella roberti Zone. Site 369A, Samples 43, CC, to 44-1.
7) Early Albian, dated by nannofossils as Parhabdolithus angustus Zone and by foraminifers as Ticinella primula Zone. Site 367 , Sample 22, CC.

8) Early Albian, dated by foraminifers as "Globigerinelloides" gyroidinaeformis Zone and by nannofossils as Parhabdolithus angustus Zone. Site 370, Samples 30-4 and 30, CC.

9) Late Aptian, dated by foraminifers as Ticinella bejaouaensis Zone and by nannofossils as Parhabdolithus angustus Zone. Site 369A, Samples 44-2 to 44, CC.

10) Late Aptian, section between the last occurrence of Hedbergella sigali and the first occurrence of Ticinella, dated by nannofossils as Parhabdolithus angustus Zone. Site 369A, Core 45, and 367, Sample 24, CC.

11) Leupoldina cabri Zone, late Aptian, dated by the co-occurrence of Hedbergella sigali and Globigerinelloides ferreolensis. Site 369A, Sections 46-2 to 464.

12a) Early Aptian, dated by nannofossils as Chiastozygus litterarius Zone and by foraminifers as section below the first occurrence of Globigerinelloides ferreolensis. Site 369A, Sample 47, CC.

12b) Early Aptian, dated by nannofossils as Chiastozygus litterarius, barren in planktonic foraminifers, Site 370 , Sections $31-4$ to $32-4$.

13) Late Barremian, dated by nannofossils as Micrantholithus hoschulzi Zone, Site 370, Samples 32, $\mathrm{CC}$ and $33, \mathrm{CC}$.

14) No older than Barremian as dated by nannofossils. Site 370, Core 34. First occurrence of Loeblichella.

15) Late Hauterivian, dated by nannofossils as no younger than late Hauterivian with the first occurrence of planktonic foraminifers at Site 370. Samples 35-1 to $37, \mathrm{CC}$.

\section{STRATIGRAPHIC CORRELATIONS TO PREVIOUS DSDP SITES IN THE NORTH ATLANTIC}

Sediments of comparable ages have been recovered during Leg 11 (Sites 101 and 105) and during Leg 15 (Sites 136, 137, 143, 144). The foraminifer stratigraphy was done by Luterbacher (1972) and Beckmann (1972), respectively.

\section{Site 136 (North of Madeira)}

Section $8-2$ to Sample $8, \mathrm{CC}$ is dominated by planktonic foraminifers (Globigerinelloides and Hedbergella) and by plant fragments. Benthic foraminifers are very scarce. This section is dated as Albian(?). Lithology is generally dark nanno ooze. Age and facies may be correlated to Aptian and Albian of Site 370 , with less terrigenous input occurring further off shore, as well as to the black shales of Sites 367,368 , and 369 .

\section{Site 137 (Between the Continental Rise and the Flank} of the Mid-Atlantic Ridge, West off Cape Blanc)

Section between $16-1$ and 16-3 (15-17 cm) is dominated by radiolarians and agglutinated benthic 


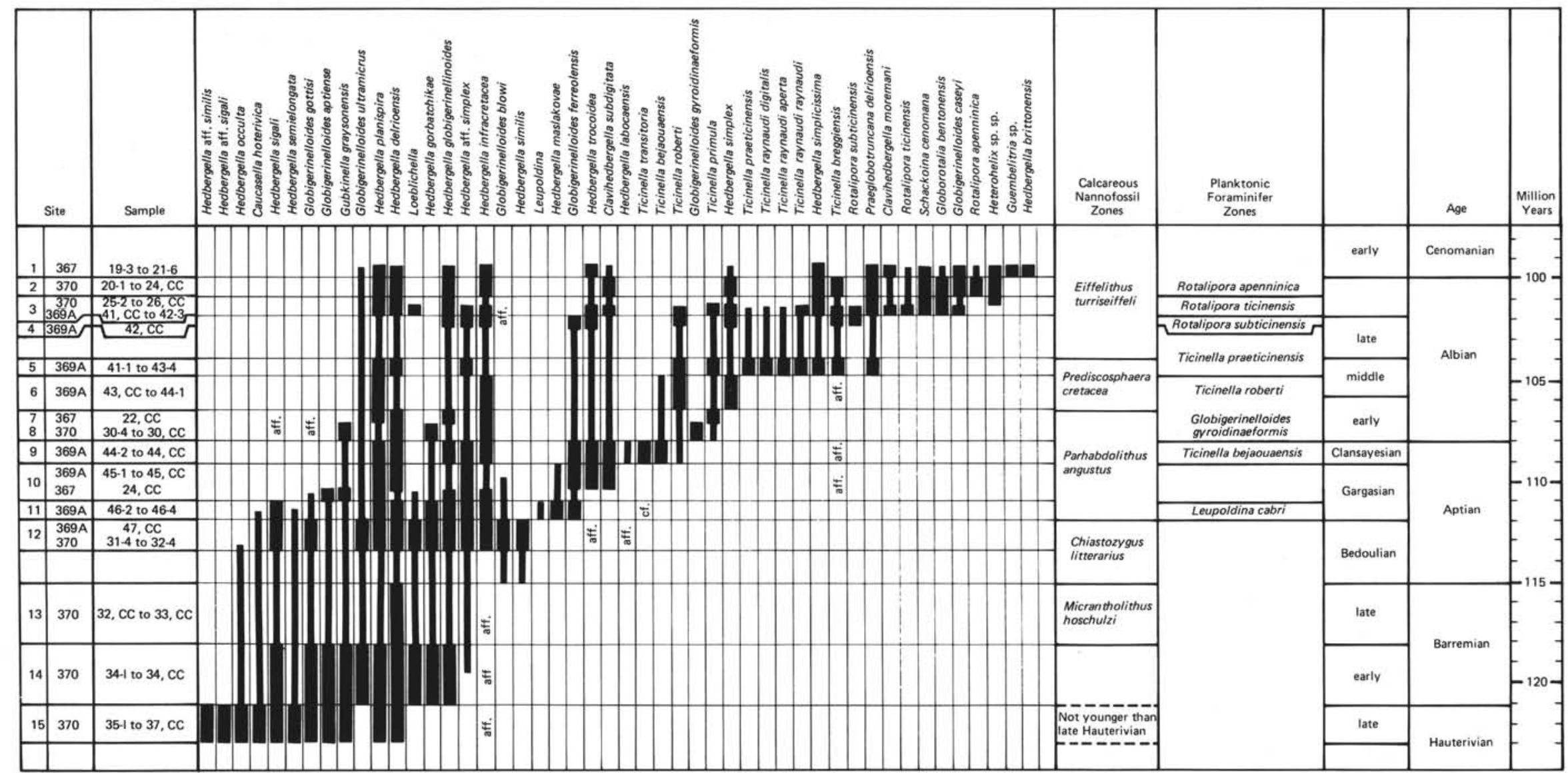

Figure 2. Ranges and zonal stratigraphy of Early Cretaceous planktonic foraminifers. Bold lines: occurrences in Leg 41-material; thin lines: connections between Leg 41-occurrences or ranges according to literature. Nanno zonation according to Čepek, this volume. Time scale according to van Hinte, 1975. 
foraminifers. Planktonic foraminifers are very scarce (Globigerinelloides caseyi, Hedbergella planispira). The age is open between Rotalipora evoluta Subzone and Rotalipora ticinensis Zone. Lithology: calcareous varicolored nanno marl and chalk oozes.

The sertion between Samples 16-3, 125-127 cm and 16 , CC contains faunas dominated by planktonic foraminifers (Hedbergella amabilis $[=H$. simplicissima $]$, Hedbergella planispira, Hedbergella trocoidea, Planomalina buxtorfi, Globigerinelloides breggiensis, Praeglobotruncana bronnimanni, Rotalipora ticinensis, Schackoina cenomana). The benthic foraminifers are quantitatively less important (Clavulina and some calcareous species). This section was dated as Vraconian, Rotalipora ticinensis Zone. The lithology is varicolored nanno marl and chalk oozes. Faunal composition is similar to Sites $369 \mathrm{~A}$ and 370 with respect to Tethyan character.

Sample SW1 contains dominantly radiolarians and planktonic foraminifers (Globigerinelloides breggiensis, Hedbergella trocoidea, Rotalipora ticinensis, and Ticinella raynaudi digitalis). Benthic foraminifers are very scarce. The age of this sample is Albian. There is no radiolarian maximum in the Albian samples.

\section{Site 143A (Foot of Demerara Rise, off Surinam)}

Samples of Core 1 contain Hedbergella amabilis ( $=H$. simplicissima), Hedbergella planispira, Hedbergella sp., and Globigerinelloides eaglefordensis $(=G$. caseyi), and some benthic foraminifers (Neobulimina is dominant). The age is AlbianCenomanian.

Site 144 (on the Flank of Demerara Rise, off Surinam)

Below late Cenomanian-early Turonian sediments there is a section of Albian to early Cenomanian age, between $5-1$ and 6, CC. The samples of Core 5 are dominated by planktonic foraminifers. Globigerinelloides bentonensis, Globigerinelloides caseyi, Hedbergella? delrioensis, Hedbergella gautierensis, Hedbergella planispira, and Hedbergella washitensis occur. The benthic foraminifer fauna is composed mainly of Neobulimina as in Site 143 samples. In the samples of Core 6 the benthic component is dominant within the foraminifers. The planktonic foraminifers are represented by Hedbergella washitensis.

The foraminifer record of the samples of Cores 7 and 8 has a dominantly benthic character. The planktonic component is mainly Guembelitria harrisi. The samples are of Albian or late Aptian age.

The faunal composition and evolution is different to the eastern Atlantic region. This may be caused by differences in water depths. By back-tracking, the depth is estimated at around 1000 meters for the Albian/Cenomanian time (Berger and von Rad, 1972).

By reconstruction of paleogeography (compare Berger and von Rad, 1972, p. 875, fig. 54) Sites 143/144 and 367 are in the same neighborhood. However, the very different facies and faunal composition during Aptian and Albian point to separate facies districts on both sides of the Mid-Atlantic ridge. The faunal evolution in the late Albian/Cenomanian time shows a more pelagic character, similar to the eastern Atlantic sites, which can be interpreted by deepening of the site in connection with a more pelagic character for the North Atlantic ocean and with less intensive barriers.

\section{Site 101A (Blake-Bahama Outer Ridge)}

Samples of Core 4 are dominated by planktonic foraminifers (Hedbergella amabilis $(=H$. simplicissima), Hedbergella trocoidea, Hedbergella planispira, Globigerinelloides eaglefordensis $(=G$. caseyi $)$, Rotalipora apenninica, Praeglobotruncana delrioensis and Schackoina cenomana bicornis. The benthic component is less frequent, mostly lagenids and some primitive agglutinated species. The age is early Cenomanian-late Albian.

Sample 5, CC, is dominated by benthic forms within the foraminifera (Spirillina, Glomospira and Hoeglundina? as main genera). The planktonics are represented by Hedbergella infracretacea. The age of this sample is Aptian/Albian.

Samples 6-1 to $10-1$ contain no planktonic foraminifers. They had been attributed to Aptian?Valanginian? and Valanginian? age. In poor preservation primitive benthic foraminifers are typical. In the lower part of this section calcareous benthic foraminifers are somewhat more common and more diverse.

\section{Site 105 (Lower Continental Rise Hills, off USA)}

A layer of black and green-gray carbonaceous clays below variegated zeolithic clay of unknown age was drilled, which contain near the top Rotalipora apenninica apenninica, Praeglobotruncana delrioensis, and Planomalina buxtorfi (Cores 11, 12). Planktonic foraminifers dominate the benthics, which are represented by some primitive agglutinated species, lagenids, and others. Among the planktonic foraminifers mentioned are: Hedbergella amabilis $(=H$. simplicissima), Hedbergella trocoidea, Hedbergella portsdownensis, Hedbergella sp. aff. Hedbergella washitensis, Hedbergella planispira. The age of this section is treated as late Albian or early Cenomanian.

In Samples 13, CC to $15, \mathrm{CC}$ no planktonic foraminifers are reported. In Core 17 the planktonic foraminifers are composed of Hedbergella globigerinelloides, Hedbergella sp. aff. Hedbergella infracretacea, Globigerinelloides ultramicrus. Some lagenids and agglutinated foraminifers are the accompanying benthics. The age is Albian to Hauterivian. Below that section no planktonic foraminifers have been encountered in the early Cretaceous profile.

Sites 101 and 105 , although presently distant from the Leg 41 sites, show a similar faunal composition and evolution during the Early Cretaceous to those at Sites 367 and 370: Scattered, poorly preserved planktonic foraminifer faunas in the Hauterivian-Albian time and the sudden evolution of Tethyan faunas with keeled planktonic foraminifers at the Albian/Cenomanian boundary, to the top of a black clay section.

\section{Summary}

If we summarize our previous knowledge of Early Cretaceous paleogeography of the North Atlantic, 
three main sections within the Early Cretaceous may be identified:

1) Earliest Cretaceous to Valanginian-no planktonic foraminifera.

2) Hauterivian to Albian-planktonic record is poor and scattered.

3) Albian to Cenomanian-planktonic record excellent, rich and diverse faunas of Tethyan character, widely distributed.

With the planktonic foraminifers we may assume that during the second interval the North Atlantic was a relatively small sea, adjacent to the Tethys, divided by the mid-oceanic ridge or ridges into several basins. Planktonic foraminifer fauna was influenced by separation, isolation, and/or dissolution.

The Albian/Cenomanian time enforces open ocean conditions with a good faunal exchange to the Tethys over great distances which may be due to a generally higher sea level or due to a subsidence of the ocean floor, while black shale conditions continue in some regions.

\section{PALEONTOLOGY}

This part contains short comments on selected species of Early Cretaceous planktonic foraminifers with respect to morphologic peculiarities and distributions. To reduce the number of plates some well-known species have not been included.

The hypotypes as well as the negatives of scanning electron micrographs are deposited in the Geological Paleontological Institute, Kiel University.

\section{Genus CAUCASELLA Longoria, 1974}

\section{Caucasella hoterivica (Subbotina)}

1953 Globigerina hoterivica-Subbotina, p. 53, pl. 1, fig. 1-3.

1974 Caucasella hauterivica (Subbotina)-Longoria, p. 49, pl. 11, fig. 9-11, 14-16.

This species has four chambers in the last whorl, a medium high spira and a wide umbilical aperture. Subbotina described it from Hauterivian of the Caucasus, according to Longoria (1974) its range is up to the basal late Aptian.

Occurrence: Section 41-370-35-5 (late Hauterivian).

\section{Genus GUBKINELLA Suleymanov, 1955}

\section{Gubkinella graysonensis (Tappan)}

(Plate 1, Figures 9-11)

1940 Globigerina graysonensis-Tappan, p. 122, pl. 19, fig. 15-17. Four globular chambers forming the last whorl, main aperture low, interiomarginal, in the middle part of the last chamber. Initial part of the spira small, acute.

The species has been recorded from upper Grayson formation, Texas, from the Lenticulina ouachensis ouachensis Zone of Trinidad. Longoria (1974) gave a range from late Aptian to Cenomanian. Occurrence: Sample 41-367-44, CC (Gargasian), Sample 41-370$37, \mathrm{CC},{ }^{\circ}$ to Section 30-4 (late Hauterivian to early Albian).

Genus HEDBERGELLA Bronnimann and Brown, 1955

\section{Hedbergella delrioensis (Carsey)}

$$
\text { (Plate 2, Figure 7a-c) }
$$

1926 Globigerina cretacea d'Orbigny var. delrioensis-Carsey, p. 43. 1974 Hedbergella delrioensis (Carsey)-Longoria, p. 54, pl. 10, fig. 1-3 (neotype).

Five to six chambers forming the last whorl, test slightly trochospiral, last chamber protruding to the small umbilicus.

In the Hauterivian and Barremian samples, we encountered specimens of similar shape, but without visible hispidity (Plate 1, Figure 8). Longoria (1974) recorded the species since the Leupoldina cabri Zone (upper Aptian) to Rotalipora evoluta Subzone (Cenomanian).
Occurrence: Sample 41-367-22, CC to Section 19-3 (early Albian to early Cenomanian), Sample 41-368-63, CC to Section 62-4 (Albian/Turonian undifferentiated), Sections 41-369A-46-4 to 42-3 (Gargasian to Rotalipora ticinensis Zone), Sections 41-370-35-5 to 201 (late Hauterivian to Rotalipora apenninica Zone).

\section{Hedbergella globigerinellinoides (Subbotina)}

1949 Globigerina globigerinellinoides-Subbotina, p. 32, pl. 7 , fig. 11-16.

Test small, with compressed spira, and almost flattened umbilical and spiral sides, six to seven chambers forming the last whorl, periphery slightly lobulate; general outline subcircular. This species has been described from Albian and Cenomanian of the Caucasus and Crimea area. Krashenninikov (1974) reported it also from DSDP Leg 27 sites in the Indian Ocean.

Occurrence: Sample 41-367-24, CC to Section 21-2 (Gargasian to Rotalipora apenninica Zone). Sample 41-369A-47, CC to 41, CC (upper Aptian to Rotalipora ticinensis Zone). Section 41-370-34-3 to Sample 20, CC, (Barremian to Rotalipora apenninica Zone).

\section{Hedbergella gorbatschikae Longoria}

1974 Hedbergella gorbatschikae-Longoria, p. 56, pl. 15, fig. 11-13. Last whorl containing five chambers, the last protruding to the umbilicus, covering it more or less. Spiral side flattened.

Range according to Longoria: late Aptian to early Albian; possibly late Albian.

Occurrence: Sections 41-369A-47-4 to 46-3 (late Aptian), Sections 41-370-34-3 to $30-4$ (Barremian to early Albian).

\section{Hedbergella infracretacea (Glasessner)}

1937 Globigerina infracretacea Glaessner, p. 28, text-fig. 1. 1966 Hedbergella infracretacea (Glaessner)-Glaessner, p. 197, pl. 1, fig. 1-3.

$H$. infracretacea contains five to five and one-half ovoidal chambers in the last whorl which increases very slightly, umbilicus deep and narrow. In Hole 369A samples five-chambered specimens are dominant in the late Aptian section, while in the Albian five and one-half chambers are more common. Differences against $H$. planispira: higher trochospiral, and narrow umbilicus, against $H$. trocoidea: lower trochospiral and lower chamber number, smoother surface, against $H$. delrionensis: last chamber shows no protrusion towards the umbilicus, ovoid in shape with longest axis in direction of growth.

Occurrence: Samples 41-367-24, CC to 17, CC (Gargasian to Upper Cretaceous), Section 41-368-62-4 (Albian/Turonian undifferentiated), Section 41-369A-47, CC to 41, CC (upper Aptian to Rotalipora ticinensis Zone), Samples 41-370-30, CC to 20, CC (early Albian to Rotalipora apenninica Zone) questionable forms from 37 , CC (late Hauterivian).

\section{Hedbergella aff. labocaensis Longoria}

Specimens with six radially elongated chambers in the last whorl and a relatively high spira have been determined as $H$. aff. lobacaensis Longoria $(1974$, p. 60$)$. The last chambers protrude somewhat to the narrow umbilicus. Longoria described this species from Hedbergella gorbatschikae to Hedbergella trocoidea Zone in the late Aptian of northern Mexico. Our specimens occur somewhat earlier in the late Aptian.

Occurrence: Section 41-369A-46-5 (late Aptian).

\section{Hedbergella maslakovae Longoria}

1974 Hedbergella maslakovae-Longoria, p. 61, pl. 24, fig. 11-12.

Mostly six, more rarely six and one-half chambers in the last whorl are radially subelongate. Spiral side concave, periphery strongly lobate, umbilicus wide. Range after Longoria: within late Aptian.

Occurrence: Section 41-369A-46-2 (Gargasian).

\section{Hedbergella occulta Longoria}

(Plate 1, Figure 12)

1974 Hedbergella occulta-Longoria, p. 63, pl. 20, fig. 8, 9.

Similar to Hedbergella trocoidea with six to seven chambers in the last whorl, but differs in the deeply incised sutures on the umbilical side and globular to ovoid chambers rather than subtriangular ones. Longoria reported the species from upper part of the Globigerinelloides gottisi Zone to lower part of Leupoldina cabri Zone. 
Occurrence: Section 41-369A-47-4 and Sample 41-370-37, CC (late Hauterivian).

\section{Hedbergella planispira (Tappan)}

(Plate 2, Figures 1-5; Plate 3, Figure 3)

1940 Globigerina planispira-Tappan, p. 122, pl. 9, fig. 12a-c.

Test with 6-8 spherical chambers in the last whorl and a wide umbilicus. Relict apertures visible in well-preserved specimens (Plate 2, Figure 1d). Earlier chambers sometimes hispid (Plate 2, Figure 4), demonstrating affinities to $H$. delrioensis. Spira almost subplanispiral.

Occurrence: Samples 41-367-33, CC to 17, CC (early Albian to upper Cretaceous), Sample 41-368-63, CC to Section 62-4 (Albian/Turonian undifferentiated), Sections $41-369 A-47-4$ to $42-1$ (late[?] Aptian to Rotalipora ticinensis Zone), Sample 41-370-37, CC to Section 20-1 (late Hauterivian to Rotalipora apenninica Zone).

\section{Hedbergella semielongata Longoria}

1974 Hedbergella semielongata-Longoria, p. 66, pl. 21, fig. 1-3.

This species is characterized by substellate, five to six chambers forming the last whorl. Longoria described it from early Aptian to basal late Aptian of Spain.

Occurrence: Sections 41-370-35-5 to 35-1 (late Hauterivian).

\section{Hedbergella sigali Moullade}

(Plate 1, Figures 1, 2)

1966 Hedbergella (Hedbergella) sigali, Moullade, p. 87, pl. 7, fig. 20-

25.

The last whorl is composed of four to four and one-half chambers with lobate periphery and narrow umbilicus.

Differs from other hedbergellas by its low number of chambers in the last whorl, from $C$. hoterivica by its low main aperture, and from Gubkinella by its low spira.

On Plate 1, Figure 3, 4 are shown four-chambered forms of larger sizes, determined as $H$. aff. sigali with respect of their poor preservation.

Occurrence: Sections 41-369A-47-5 to 46-2 (late Aptian), Sample 41-370-37, CC to Section 34-2 (late Hauterivian to Barremian).

\section{Hedbergella similis Longoria}

1974 Hedbergella similis-Longoria, p. 68, pl. 16, fig. 19-21.

Similar to Hedbergella planispira, but with elongated chambers in the last whorl. Range according to Longoria: lower Aptian to basal upper Aptian.

Occurrence: Sections 41-369A-47-5 to 47-2 (late[?] Aptian).

\section{Hedbergella aff. similis Longoria}

(Plate 1, Figure 5)

Rare specimens with five chambers in the last whorl, a wide umbilicus, and a distinctly lobate periphery have been attributed to $H$. aff. similis. The preservation, however, is not sufficient to a definite determination.

Occurrence: Sections 41-369A-47-5 to 46-2 (late[?] Aptian), Sample 41-370-37, CC (late Hauterivian).

\section{Hedbergella simplicissima (Magné and Sigal) (Plate 2, Figures 8-10)}

1954 Hastigerinella simplicissima-Magné and Sigal, p. 487, pl. 14, fig. 11 (fide Catalogue of Foraminifera).

1961 Hedbergella amabilis Loeblich and Tappan, p. 274, pl. 3, fig. 1-

10.

We have encountered the same variability of the species from subelongate to clavate chambers as figured by Loeblich and Tappan (1961) sub Hedbergella amabilis. As Hedbergella simplicissima falls into the same spectrum it has priority in nomenclature (see Caron, 1966). Herb (1974) pointed to the same kind of hispid surfaces of the tests of $H$. simplicissima and $H$. delrioensis. Plate 2, Figures 7c and $10 \mathrm{~b}$ confirm that statement. These figures demonstrate that spines are not restricted to the Neogene Globigerinacea. Additional investigations will clarify the nature of these "spines."

The species had been described from Albian and Cenomanian (mostly sub H. amabilis), according to Caron (1966) and continues up to Santonian.
Several very small specimens were encountered in our material, down to Aptian strata which resemble the outline of $H$. simplicissima. However preservation is too poor for an exact determination.

Occurrence: Section 41-367-19-3 to Sample 22, CC (Albian to Cenomanian), Sample 41-369A-41, CC to Section 43-4 (middle and late Albian), Section 41-370-20-1 to Sample 24, CC (Vraconian/Cenomanian).

\section{Hedbergella trocoidea (Gandolfi)}

1942 Anomalina lorneiana (d'Orbigny) var. trocoidea-Gandolfi, p. 99 , pl. 2, fig. 3-5.

1969 Hedbergella trocoidea (Gandolfi)-Caron and Luterbacher, p. 23, pl. 7, fig. 1, 2a-c (lectotype).

This species had been described from late Aptian to Albian section of Switzerland, Bavaria, France, Trinidad, Rumania, and Mexico.

Occurrence: Sample 41-367-24, CC to Section 21-2 (Gargasian to Rotalipora apenninica Zone), Sections 41-368-62-4 (Albian/Turonian undifferentiated), Samples 41-369A-47, CC to $41, C C$ (Bedoulian to Rotalipora ticinensis Zone), Samples 41-370-28, CC (Albian).

Genus CLAVIHEDBERGELLA Banner and Blow, 1959

\section{Clavihedbergella moremani (Cushman)}

(Plate 7, Figures 2, 3)

1931 Hastigerinella moremani-Cushman, p. 11, fig. 1.

1961 Clavihedbergella moremani (Cushman)-Loeblich and Tappan, p. 279 , pl. 5, fig. 12-16.

Our species concept conforms with that of Loeblich and Tappan (1961). However, our specimens do not reach the dimensions of the figured hypotypes.

The species had been described from the Cenomanian of Texas and Gulf Coastal region. The genus is ranging from Aptian to Turonian (Loeblich and Tappan, 1961, p. 279).

Occurrence: Section 41-369-42-2 (Rotalipora ticinensis Zone).

\section{Clavihedbergella subdigitata (Carman)}

1929 Globigerina subdigitata-Carman, p. 315, pl. 34, fig. 4, 5 .

1971 Clavihedbergella subcretacea (Tappan)-Caron, p. 148, fig. 6.

Six to eight radially elongate chambers form the last coil. In the lower part of the species range only the last chamber is distinctly elongate. Umbilicus is wide, coiling is very slightly trochospiral. In peripheral view the chambers are slightly compressed. From Hedbergella bollii Longoria, it differs in the closer arrangement and the more clavate outline of the chambers. From $C$. subcretacea, it differs in the less rapid prolongation of the chambers and the less deeply lobulate periphery. Hedbergella maslakovae has a similar umbilicus, but the chambers are less elongate. $H$. semielongata has fewer chambers in the last whorl.

Occurrence: Sections 41-369A-45-4 to $42-2$ (Gargasian to Rotalipora ticinensis Zone), Section 41-370-22-1 to Sample 20, CC (Rotalipora apenninica Zone).

Specimens with radially elongated chambers six in the last whorl, the last ${ }^{\circ}$ two or three digitate, but with not as deeply lobulated periphery as given for $H$. subcretacea (Tappan) have been encountered in Hole 369A, Sections 46-2, 3, 4, and 47-5 in small specimens. These samples are believed being of upper Aptian age. Our specimens resemble to the figure given by Kuhry (1971, pl. 2, fig. 1) as Hedbergella sp. aff. Ticinella digitalis Sigal, but have a narrower umbilicus.

Occurrence: Sample 41-369A-47, CC to Section 42-2 (Bedoulian to Rotalipora ticinensis Zone), Sample 41-370-33, CC (Barremian).

\section{Genus LOEBLICHELLA Pessagno, 1967}

\section{Loeblichella sp. aff. convexa Longoria}

(Plate 1, Figures 6, 7)

Specimens, which resemble the figures given by Longoria (1974) are rare; the determination is given in open nomenclature, as their preservation is very poor and mostly compressed. $L$. convexa had been described from late Aptian (Mexico, France).

Occurrence: Sections 41-369A-47-5 to 47-2 (Aptian), questionable forms in Sample 41-369A-42, CC (Rotalipora subticinensis Zone), Section 41-370-34-2 (Barremian). 
Genus GLOBIGERINELLOIDES Cushman and Ten Dam, 1948

Globigerinelloides aptiensis Longoria

1974 Globigerinelloides aptiense-Longoria, p. 79, pl. 4, fig. 9-10

Five to five and one-half chambers forming the last whorl, periphery strongly lobate, umbilicus wide, spira evolute.

Longoria reported this species from Globigerinelloides ferreolensis Zone (late Aptian) of the Gargas stratotype.

Occurrence: Sample 41-367-24, CC (Gargasian), Sections 41-37035-5 to 34-3 (late Hauterivian to Barremian).

\section{Globigerinelloides bentonensis (Morrow)}

(Plate 3, Figures 6, 7)

1934 Anomalina bentonensis Morrow, p. 201, pl. 30, fig. 4a-6.

1961 Globigerinelloides bentonensis (Morrow)-Loeblich and Tappan, p. 267, pl. 2, fig. 8-10.

This species differs from Globigerinelloides caseyi in the more involute coiling. According to Moullade (1966, p. 126) however this difference falls within the variability of the species.

The species had been reported from late Albian and Cenomanian of the USA, France, and Bavaria.

Occurrence: 41-367-22-5 (Cenomanian), Samples 41-369A-42, CC (Rotalipora ticinensis Zone), Samples 41-370-24, CC to 21, CC (Rotalipora apenninica Zone).

\section{Globigerinelloides blowi (Bolli)}

1959 Planomalina blowi-Bolli, p. 260, pl. 20, fig. 6.

Five to six chambers form the involute last coil. Umbilicus shallow, wide.

This species had been recorded from Aptian strata of Trinidad, France, Bavaria, Mexico, and Spain. Longoria (1974) reported its range from early Aptian to Hedbergella gorbatchikae Zone (late Aptian).

Occurrence: Sample 41-369A-47, CC (Bedoulian), questionable Sample 41-369A-42, CC (Rotalipora subticinensis Zone).

\section{Globigerinelloides caseyi (Bolli, Loeblich, and Tappan)}

$$
\text { (Plate 3, Figures 5, 8, 9) }
$$

1957 Planomalina caseyi-Bolli, Loeblich, and Tappan, p. 24, pl. I, fig. 4-5.

1970 Globigerinelloides caseyi (Bolli, Loeblich, and Tappan)-Eicher and Worstell, p. 197, pl. 8, fig. 11, 15a, b, 16.

Though Moullade (1966, p. 126) and Risch (1971, p. 124) state that $G$. caseyi is a junior synonym of $G$. bentonensis, we tried to follow the concept of Eicher and Worstell. The occurrence of both species, however, starts within the same interval of our material.

Occurrence: Sections 41-367-22-5 to 19-3 (Albian to Cenomanian), Section 41-369A-42-3 (Rotalipora ticinensis Zone), Samples 41-370-24, CC to 20, CC (Rotalipora apenninica Zone).

\section{Globigerinelloides ferreolensis (Moullade)}

(Plate 3, Figure 1a-c)

1961 Biticinella ferreolensis-Moullade, p. 14, pl. 1, fig. 1-5.

Our material shows specimens mostly with only seven chambers in the last whorl, eight-chambered forms are not so common. The species had been recorded from lower Gargasian in France, uppermost Aptian to lower Albian of Bavaria, late Aptian of Spain, and Mexico.

Occurrence: Sections 41-369A-46-4 to 42-3 (upper Aptian to Rotalipora ticinensis Zone).

\section{Globigerinelloides gottsisi (Chevalier)}

(Plate 3, Figures 2, 4)

1961 Globigerinella gottisi-Chevalier, p. 32, pl. 1, fig. 9a, b.

Four to five spherical chambers forming the last whorl, spira slightly evolute. According to Longoria (1974, p. 85), it differs from G. blowi by its ovate peripheral outline and by its semievolute coiling. The type comes from the Gargasian of France; Longoria reported it from early Aptian to lower part of Globigerinelloides ferreolensis Zone of the late Aptian with occurrences in Crimea, Mexico, Spain, and California.

Occurrence: Samples 41-369A-47, CC to 46, CC (Aptian), Sections 41-370-35-1 to 34-2 (late Hauterivian to Barremian).
Globigerinelloides gyroidinaeformis Moullade

(Plate 1, Figures 13-15)

1966 "Globigerinelloides" gyroidinaeformis Moullade, p. 128, pl. 9, fig. 16-22.

Test pseudoplanispirally coiled, strongly involute, with four to five chambers forming the last whorl, chamber diameter rapidly increasing as well in axial as equatorial directions, umbilicus closed. Attribution to the genus Globigerinelloides is under discussion.

The species had been recorded from early and middle Albian of France (Moullade, 1966); Bavaria (Risch, 1971); and Indian Ocean (Krasheninnikov, 1974).

Occurrence: Sample 41-370-30, CC to Section 30-4 (early Albian).

\section{Globigerinelloides ultramicrus (Subbotina)}

1949 Globigerinella ultramicra-Subbotina, p. 33, pl. 1, fig. 17, 18. Very small, thin-walled specimens with six to eight spherical chambers, very slowly increasing, form the last whorl: Umbilicus wide and shallow, coiling slightly evolute. This species is known from Albian-Cenomanian of the Caucasus, Crimea, Carpathians, and Indian Ocean.

Occurrence Sample 41-369A-47, CC (Bedoulian), Samples 41-370$35, \mathrm{CC}$ to $33, \mathrm{CC}$ (late Hauterivian to Barremian).

Genus SCHACKOINA Thalmann, 1932

\section{Schackoina cenomana (Schacko)}

(Plate 6, Figures 5-7)

1897 Siderolina cenomana-Schacko, p. 166, pl. 4, fig. 3-5.

1961 Schackoina cenomana (Schacko)-Loeblich and Tappan, p. 270 , pl. 1, fig. 2-7.

This tiny species, often smaller than $120 \mu \mathrm{m}$ in diameter, has been recorded from Cenomanian rocks nearly all over the world. Late Albian occurrences have been reported by Herb (1974) from the eastern Indian Ocean.

Occurrence: Sections 41-367-21-6 to 20-2 (Rotalipora apenninica Zone), Sample 41-369A-42, CC to Section 41-2 (Rotalipora subticinensis to Rotalipora ticinensis Zone), Samples 41-370-24, CC to 20, CC (Rotalipora apenninica Zone).

\section{Genus PRAEGLOBOTRUNCANA Bermudez, 1951}

\section{Praeglobotruncana delrioensis (Plummer)}

(Plate 4, Figures 1-3)

1931 Globorotalia delrioensis-Plummer, p. 199, pl. 13, fig. 2.

According to Loeblich and Tappan (1961, p. 282), the species differs from the similar Praeglobotruncana stephani by its nearly biconvex shape and rounded chambers, while $P$. stephani is planoconvex and has angular to rhomboidal chambers. Additional $P$. stephani has somewhat larger sizes.

The species is known from late Albian and Cenomanian of Southern USA, Trinidad, Switzerland, and Bavaria.

Occurrence: Section 41-367-19-3 (Cenomanian), Sections 41369A-43-1 to 42-1 (Ticinella praeticinensis Zone to Rotalipora ticinensis Zone), Sample 41-370-26, CC to Section 20-1 (Rotalipora ticinensis Zone to Rotalipora apenninica Zone).

\section{Genus TICINELLA Reichel, 1950}

\section{Ticinella bejaouaensis Sigal}

1966 Ticinella roberti var. bejaouaensis-Sigal, p. 207, pl. 5, fig. 5a$9 \mathrm{~b}$.

Test low spirally coiled, 8-10 chambers forming the last whorl, wide umbilicus and small supplementary apertures. The species is known from uppermost Aptian and early Albian strata.

Occurrence: Sections 41-369A-44-3 to 44-1 (Clansayesian to Ticinella roberti Zone).

\section{Ticinella breggiensis (Gandolfi) (Plate 5, Figure 5a-c)}

1942 Anomalina breggiensis-Gandolfi, p. 102, pl. 3, fig. 6. 1969 Biticinella breggiensis (Gandolfi)-Caron and Luterbacher, p. 25 , pl. 7 , fig. 4 (holotype redrawn).

The generic position of this species is under discussion, as the pseudoplanispiral test shows relict apertures on the spiral side like 
Globigerinelloides and accessory apertures of Ticinella type on the umbilical side. Our material has generally smaller chamber numbers in the last whorl $(71 / 2-8)$ instead of nine as given in the holotype.

Specimens of Globigerinelloides - features, which have nearly the same outline as the middle and late Albian forms have been met since late Aptian in Hole 369A.

Occurrence: Sections 41-369A-43-1 to 42-1 (Ticinella praeticinensis Zone to Rotalipora ticinensis Zone), Section 41-370-20-1 (Rotalipora apenninica Zone).

\section{Ticinella praeticinensis Sigal}

1966 Ticinella praeticinensis Sigal, p. 195, pl. 2, fig. 3a, b-5a, b.

This species is intermittent between Ticinella and Rotalipora, as its periphery is rounded-subrounded, but covered by pustules, which unite especially in the earlier whorls. The peripheral view shows a subangular outline.

Its occurrence in Hole $369 \mathrm{~A}$ is in the upper part of the range of Ticinella roberti and in the basal part of Rotalipora ticinensis Zone, (Sections 43-4 to 43-1) few to rare.

\section{Ticinella primula Luterbacher}

(Plate 4, Figures 4-7)

1963 Ticinella primula Luterbacher in Renz et al., p. 1085, fig. 4a-c.

Test low trochospiral, last whorl formed by six to eight chambers laterally slightly appressed, umbilicus rather wide and shallow. Secondary apertures especially on the last chambers are distinctly sutural elongated slits.

There have been encountered specimens with distinctly elongated last chambers, which resemble the figures given by Caron (1971, p. 151 , fig. 12a-c).

Occurrence: $41-367-22, \mathrm{CC}$ to $21, \mathrm{CC}$ (early Albian to Cenomanian), $41-369 \mathrm{~A}-43-4$ to $42-1$ (Ticinella praeticinensis Zone to Rotalipora ticinensis Zone).

\section{Ticinella raynaudi raynaudi Sigal}

1966 Ticinella raynaudi raynaudi Sigal, p. 201, pl. 5, fig. 4a, b, pl. 6, fig. 1-3.

Test slightly trochospiral, mostly six chambers in the last whorl which in both axial views are of nearly spherical shape.

Umbilicus fairly wide and shallow, supplementary apertures small, restricted to the innermost parts of the sutures.

Occurrences: Sample 41-367-22, CC and Section 22-5 (early Albian), Sections 41-369A-43-3 to 41-3 (Ticinella praeticinensis Zone to Rotalipora ticinensis Zone).

\section{Ticinella raynaudi digitalis Sigal}

(Plate 5, Figures 3, 4)

1966 Ticinella raynaudi var. digitalis-Sigal, p. 202, pl. 4, fig. 6a, b-

$8 \mathrm{a}, \mathrm{b}$.

This subspecies with radially elongated last chambers had been reported from late Albian sections of Madagascar and Switzerland (Sigal 1966) and Bavaria (Risch, 1971).

Occurrence: Sections 41-369A-43-3 to 43-2 (Ticinella praeticinensis Zone)

\section{Ticinella raynaudi aperta Sigal}

(Plate 5, Figures 1, 2)

1966 Ticinella raynaudi var. aperta-Sigal, p. 202, pl. 4, fig. 11a, b$13 \mathrm{a}, \mathrm{b}$.

The subspecies differs from Ticinella raynaudi raynaudi in its more evolute coiling. According to Sigal (1966) it is evolving in the upper half of the species range.

Occurrence: Section 41-369A-43-1 (Ticinella praeticinensis Zone).

\section{Ticinella roberti (Gandolfi)}

(Plate 4, Figures 8, 9)

1942 Anomalina roberti Gandolfi, p. 100, pl. 2, fig. 2

Remarks: We have encountered distinctly trochospiral as well as subplanispiral specimens in our material. ${ }^{\circ}$ The species ranges in Hole 369A samples from Section 44-1 to Sample 41, CC (Ticinella roberti to Rotalipora ticinensis Zone).

\section{Ticinella transitoria Longoria}

1974 Ticinella bejaouaensis transitoria-Longoria, p. 95, pl. 21, fig. 9-11, 14-16.
Ticinellas with very small accessory apertures, small umbilicus, medium-high spired, and with six to seven chambers forming the last whorl. They differ from $T$. roberti by the smaller umbilicus, in having long apertural portici, and lower chamber number in the last whorl, from Hedbergella species in the supplementary apertures. These forms are believed to be the most primitive ticinellas. Risch (1969) and Longoria (1974) reported the earliest occurrence of such forms in the uppermost Aptian (Clansayesian).

Occurrence: Sections $41-369 \mathrm{~A}-44-3$ to $44-1$ (Clansayesian to Ticinella roberti Zone). Questionable forms in Section 41-369A-46-3 (Gargasian).

\section{Genus ROTALIPORA Brotzen, 1942}

Rotalipora apenninica (Renz)

(Plate 7, Figures 1, 4)

1936 Globotruncana appenninica-Renz, p. 14, fig. 2.

1969 Rotalipora apenninica (Renz)-Caron and Luterbacher, p. 26, pl. 8 , fig. 8 .

In peripheral view our specimens are generally between the figures given by Caron and Luterbacher (1969) for $R$. apenninica and $R$. gandolfii. The chambers are yet more radially elongate on the spiral side and rather biconvex. Some rare specimens in the higher part of the section show transitional features to $R$. cushmani. Range according to van Hinte (1975) since uppermost Vraconian to early Cenomanian.

Occurrence: Sample 41-370-24, CC to Section 20-1 (Rotalipora apenninica Zone).

\section{Rotalipora subticinensis (Gandolfi) (Plate 6, Figure 3)}

1957 Globotruncana (Thalmanninella) ticinensis subticinensis Gandolfi, p. 59, pl. 8, fig. 1a-c.

This species is very rare in Hole 369A: Samples 42-2, -3, CC occurring slightly before and within the range of $R$. ticinensis. Transitional forms between $R$. ticinensis and $R$. subticinensis are more common (Plate 6, Figure 4).

\section{Rotalipora ticinensis (Gandolfi) \\ (Plate 6, Figures 1, 2)}

1942 Globotruncana ticinensis typica-Gandolfi, p. 113, pl. 2, fig. 3a-c; pl. 4, fig. 10, 11, 23; pl. 5, fig. 2,4 .

Small specimens attributed to this species are rare to few in Sections 369A-43-1 to 41-3 (Rotalipora ticinensis Zone).

\section{ACKNOWLEDGMENTS}

We wish to acknowledge the Deep Sea Drilling Project for providing the opportunity to participate on Leg 41 and the Geological Institute of the Academy of Sciences of the USSR and the Geological Paleontological Institute of the Kiel University for leave. We received technical help from Mrs. C. Schulz, Mr. Reimann, and Mr. W. Rösler. The English text had been revised by $\mathbf{M}$. Whiticar. This contribution was supported by Deutsche Forschungsgemeinschaft (German research society).

\section{REFERENCES}

Beckmann, J.P., 1972. The foraminifera and some associated microfossils of Sites 135 to 144. In Hayes, D.E., Pimm, A.C., et al., Initial Reports of the Deep Sea Drilling Project, Volume 14: Washington (U.S. Government Printing Office), p. 389.

Berger, W.H. and von Rad, U., 1972. Cretaceous and Cenozoic sediments from the Atlantic Ocean. In Hayes, D.E., Pimm, A.C., et al., Initial Reports of the Deep Sea Drilling Project, Volume 14: Washington (U.S. Government Printing Office), p. 787.

Bolli, H.M., 1959. Planktonic foraminifera from the Cretaceous of Trinidad, B.W.I.: Am. Paleontol. Bull., v. 39 , p. 257. 
Bolli, H.M., Loeblich, A.R., Jr., and Tappan, H., 1957. Planktonic foraminiferal families Hantkeninidae, Orbulinidae, Globorotaliidae and Globotruncanidae: U.S. Nat. Mus. Bull. 215, p. 1.

Carman, K., 1929. Some foraminifera from the Niobrara and Benton Formation of Wyoming: J. Paleontol., v. 3, p. 309.

Caron, M., 1971. Quelques cas d'instabilité des caractères génériques chez les foraminiferes planctoniques de l'Albien: Second Plankt. Conf. Froc., Roma, 1970, v. 1, p. 145 .

Caron, M. and Luterbacher, H.P., 1969. On some type specimens of Cretaceous planktonic foraminifera: Contrib. Cushman Found. Foram. Res., v. 20, p. 23.

Carsey, D.O., 1926. Foraminifera of the Cretaceous of Central Texas: Univ. Texas Bull. 2612.

Chevalier, J., 1961. Quelques nouvelles espècies de Foraminiferes dans le Crétacé inférieur méditerranéen: Rev. Micropaleontol., v. 4, p. 30.

Cushman, J.A., 1931. Hastigerinella and other interesting foraminifera from the Upper Cretaceous of Texas: Cushm. Lab. Foram. Res., Contrib., v. 7-4, p. 83.

Eicher, D.L. and Worstell, P., 1970. Cenomanian and Turonian foraminifera from the Great Plains, United States: Micropaleontology, v. 16, p. 269.

Gandolfi, R., 1942. Richerche micropaleontologiche e stratigrafiche sulla Scaglia e sul flysch Cretacici: Rev. Ital. Paleontol. Mem. 4, p. 1.

1957. Notes on some species of Globotruncana: Contrib. Cushman Found. Foram. Res., v. 8, p. 59.

GlaessnerCM.F., 1937. Planktonforaminiferen aus der Kreide und dem Eozän und ihre stratigraphische Bedeutung: Moskow Univ., Lab. Paleontol., Studies in Micropal., v. 1, p. 27.

1966. Notes on Foraminifera of the Genus Hedbergella: Eclog. Geol. Helv., v. 59, p. 179.

Herb, R., 1974. Cretaceous planktonic foraminifera from the eastern Indian Ocean. In Davies, T.A., Luyendyk, B.P., et al., Initial Reports of the Deep Sea Drilling Project, Volume 26: Washington (U.S. Government Printing Office), p. 745 .

Kuhry, B., 1971. Lower Cretaceous Planktonic Foraminifera from the Miravetes, Argos and Represa Formations (S.E. Spain): Rev. Esp. Micropaleont., v. 3, p. 219.

Krasheninnikov, V.A., 1974. Cretaceous and Paleogene planktonic foraminifera, Leg 27 of the Deep Sea Drilling Project. In Veevers, J.J., Heirtzler, J.R., et al., Initial Reports of the Deep Sea Drilling Project, Volume 27: Washington (U.S. Government Printing Office), p. 663.
Loeblich, A.R., Jr., and Tappan, H., 1961. Cretaceous planktonic foraminifers: Part 1-Cenomanian: Micropaleontology, v. 7, p. 257.

Longoria, J.F., 1974. Stratigraphic, morphologic and taxonomic studies of Aptian planktonic foraminifera: Rev. Esp. Micropaleont., num. extraord., 1974, p. 11.

Luterbacher, H.P., 1972. Foraminifera from the Lower Cretaceous and Upper Jurassic of the Northwestern Atlantic. In Hollister, C.D., Ewing, J.I., et al., Initial Reports of the Deep Sea Drilling Project, Volume 11: Washington (U.S. Government Printing Office), p. 561.

Morrow, A.L., 1934. Foraminifera and Ostracoda from the Upper Cretaceous of Kansas: J. Paleontol,, v. 8, p. 186.

Moullade, M., 1961. Quelques Foraminiferes et Ostracodes nouveaux du Crétacé inférieur vocontien: Rev. Micropaleontol., v. 3, p. 131 . 1966. Etude stratigraphique et micropaléontologique du Crétacé inférieur de la "Fosse vocontienne". Doc. Lab. Géol. Fac. Sci., v. 15, p. 1.

Plummer, H.J., 1931. Some Cretaceous Foraminifera in Texas: Univ. Texas Bull., 3101, p. 109.

Renz, O., 1936. Stratigraphische und mikropalëontologische Untersuchungen der Scaglia (Obere Kreide-Tertiär) im zentralen Appennin: Eclog. Geol. Helv., v. 29, p. 1.

Renz, O., Luterbacher, H.P., and Schneider, A., 1963. Stratigraphisch-paläontologigische Untersuchungen im Alb und Cenoman des Neuenburger Jura: Eclog. Geol. Helv., v. 56, p. 1073.

Risch, H., 1969. Stratigraphie der höheren Unterkreide der bayerischen Kalkalpen mit Hilfe von Mikrofossilien: Dissertation Univ. München.

Schacko, G., 1897. Beitrag über Foraminiferen aus der Cenoman-Kreide von Moltzow in Mecklenburg: Ver. Freunde Naturges. Mecklenburg, Archiv., v. 50, p. 161.

Sigal, J., 1966. Contribution à une monographie des Rosalines I. Le genre Ticinella Reichel, souche des Rotalipores: Eclog. Geol. Helv., v. 59, p. 185.

Subbotina, N.N., 1949. Microfauna of the USSR Petroleum districts. Monographic study of the foraminiferal fauna in the Lower Cretaceous deposits of southern Emba district: Microfauna SSSR, trudy VNIGRI, 2, n. ser., p. 5. 1953. Fossil Foraminifera of the USSR. Globigerinidae, Hantkeninidae and Globorotaliidae: Trudy VNIGRI, v. 76 , p. 1.

Tappan, H., 1940. Foraminifera from the Grayson formation of northern Texas: J. Paleontol., v. 14, p. 93.

van Hinte, J.E., 1975. Cretaceous time-scale: manuscript. 



\section{PLATE 1}

Figures 1, 2 Hedbergella sigali Moullade. Sample 370-34-2, 73-75 cm.

1a. Spiral view, $\times 300$.

1b. Peripheral view, $\times 300$.

2. Umbilical view, $\times 300$.

Figures 3,4 Hedbergella aff. sigali Moullade.

Sample 370-37, CC.

3. Umbilical view, $\times 300$.

4 a. Peripheral view, $\times 300$.

4b. Spiral view, $\times 300$.

Figure $5 \quad$ Hedbergella aff. similis Longoria.

Sample 370-37, CC.

Umbilical view, $\times 300$.

Figures 6,7 Loeblichella moulladei Longoria.

Sample 370-34-2, 73-75 cm.

6. Umbilical view, $\times 300$.

7. Spiral view, $\times 300$.

Figure $8 \quad$ Hedbergella aff. delrioensis (Carsey).

Sample 370-37, CC.

Umbilical view, $\times 300$.

Figures 9-11 Gubkinella aff. graysonensis (Tappan).

Sample $367-24$, CC.

9. Spiral view, $\times 300$.

10. Peripheral view, $\times 300$.

11. Umbilical view, $\times 300$.

Figure 12 Hedbergella occulta Longoria.

Sample 370-37, CC.

Umbilical view, $\times 300$.

Figures 13-15 "Globigerinelloides" gyroidinaeformis (Moullade). Sample 370-30-4, 53-55 cm.

13. Umbilical view, $\times 150$.

14. Peripheral view, $\times 150$.

15. Spiral view, $\times 150$. 


\section{PLATE 1}

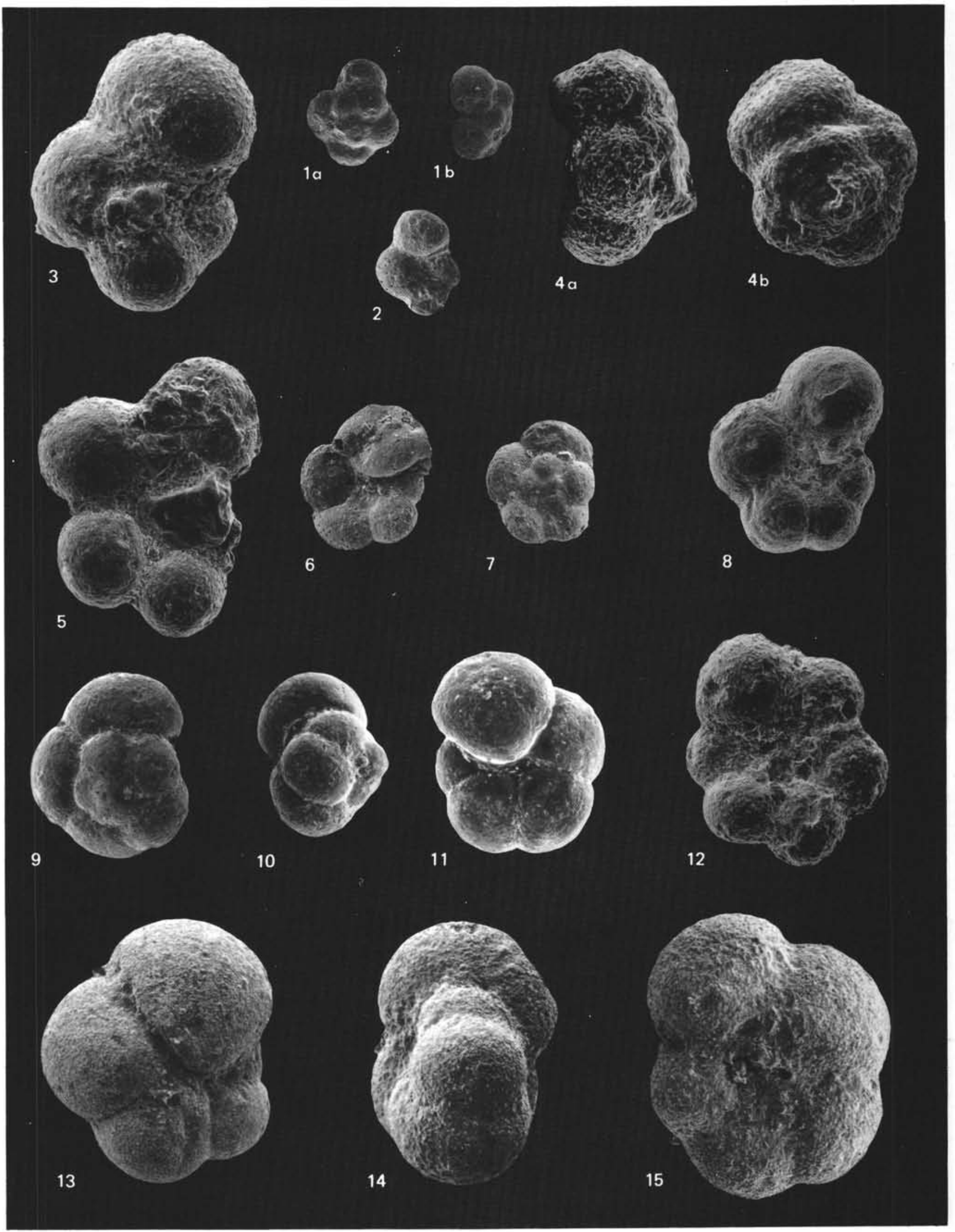




\section{PLATE 2}

Figure 1

Hedbergella planispira (Tappan).

Sample 369A-43-3, 63-65 cm.

1a. Spiral view, $\times 150$.

1b. Peripheral view, $\times 150$.

1c. Umbilical view, $\times 150$.

1d. Detail of the umbilical region, $\times 250$.

Figures 2, $3 \quad$ Hedbergella planispira (Tappan).

Sample 370-20-1, 73-75 cm.

2. Spiral view, $\times 150$.

3. Umbilical view, $\times 150$.

Figure 4 Hedbergella planispira (Tappan).

Sample 370-24, CC.

Umbilical view, $\times 150$.

Figure 5 Hedbergella planispira (Tappan).

Sample 370-24-5, 73-75 cm.

Ultrastructure of the spiral sice of the last chamber, $\times 1000$.

Figure $6 \quad$ Hedbergella cf. delrioensis (Carsey).

Sample 370-24-5, 73-75 cm.

Umbilical view, $\times 300$.

Figure $7 \quad$ Hedbergella delrioensis (Carsey).

Sample 370-24, CC.

7a. Umbilical view, $\times 150$.

7b. Peripheral view, $\times 150$.

7c. Ultrastructure of the umbilical side of the last chamber, $\times 1000$.

Figure $8 \quad$ Hedbergella simplicissima (Mangé and Sigal).

Sample 367-21, CC.

Umbilical view, $\times 150$.

Figure 9 Hedbergella simplicissima (Mangé and Sigal).

Sample 367-21, CC.

Spiral view, $\times 150$.

Figure 10 Hedbergella simplicissima (Mangé and Sigal).

Sample 370-24, CC

10a. Umbilical view, $\times 150$.

10b. Ultrastructure of the umbilical side of the penultimate chamber, $\times 1000$. 


\section{PLATE 2}
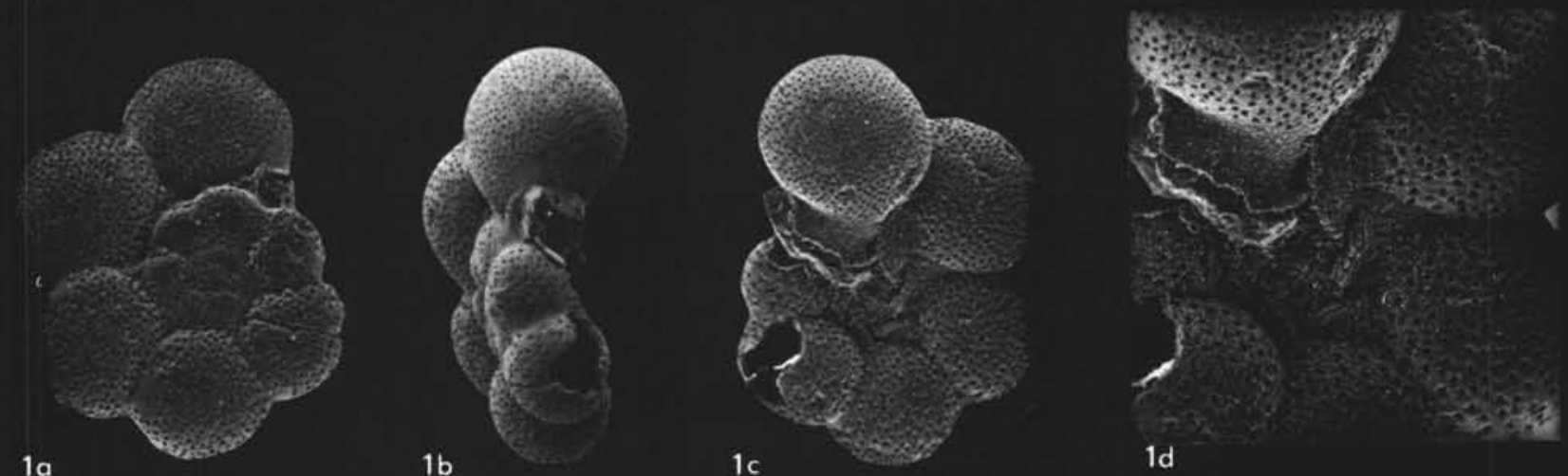

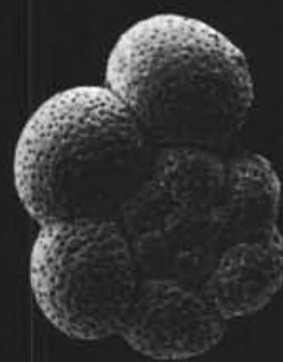

2

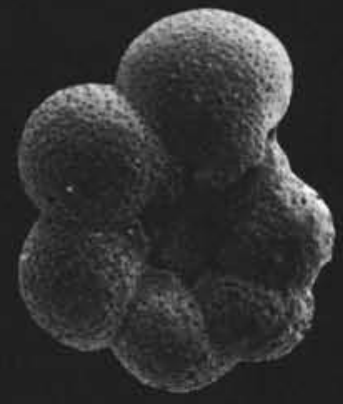

3

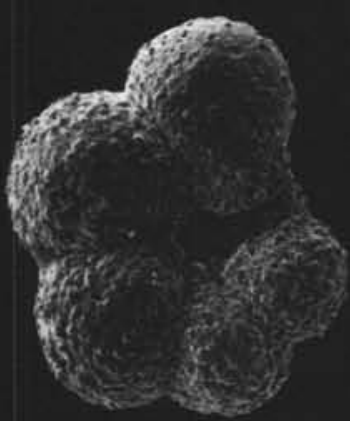

6

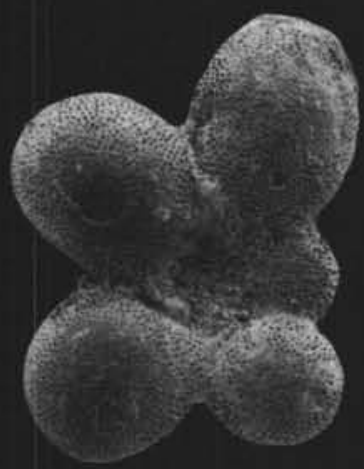

8

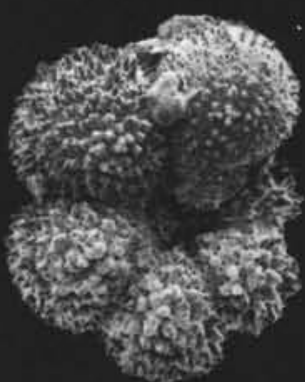

$7 a$

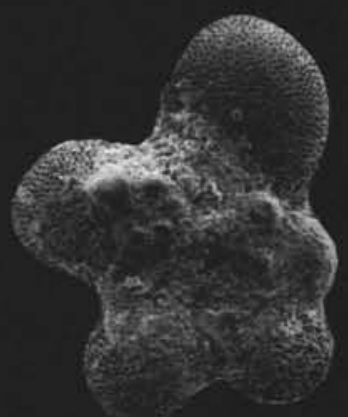

9

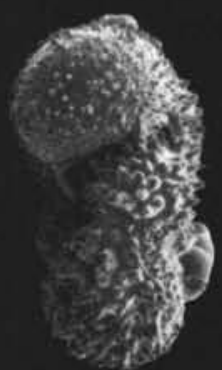

$7 b$

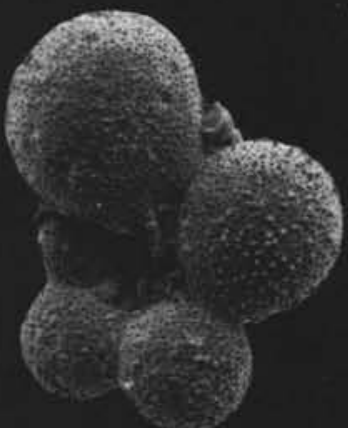

$10 a$
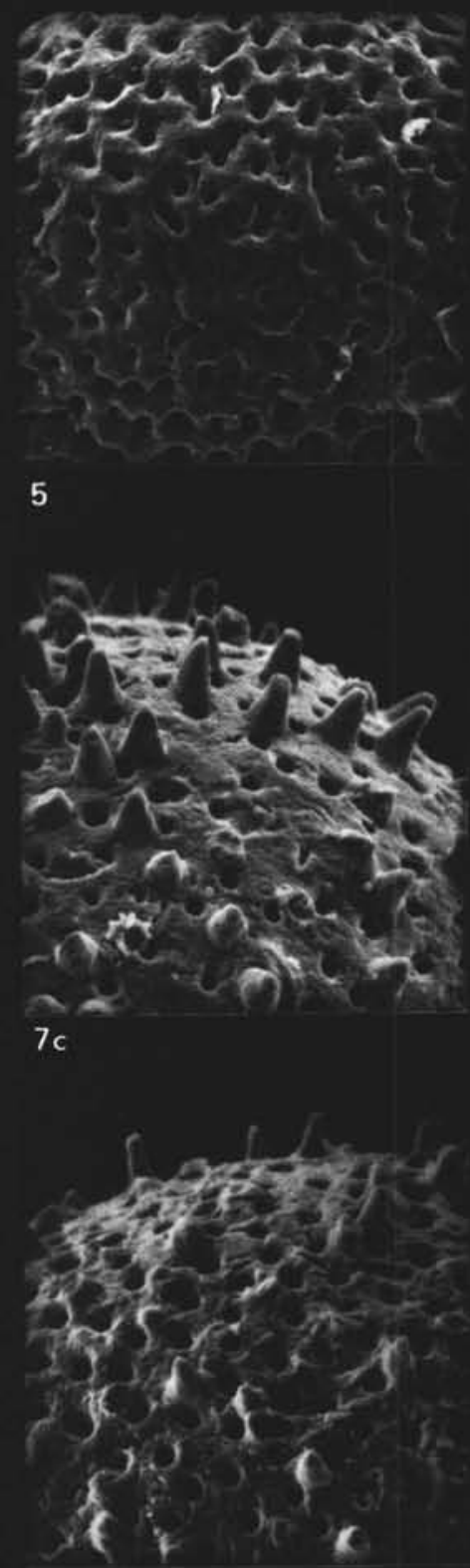

$10 \mathrm{~b}$ 


\section{PLATE 3}

Figure 1 Globigerinelloides ferreolensis (Moullade).

Sample 369A-45, CC.

1a. Lateral view, $\times 150$.

1b. Peripheral view, $\times 150$.

1c. Detail of the umbilical region, $\times 500$.

Figure 2 Globigerinelloides gottisi (Chevalier).

Sample 370-34-2, 73-75 cm.

2a. Peripheral view, $\times 600$.

2b. Lateral view, $\times 600$.

Figure 3 Hedbergella planispira (Tappan).

Sample 370-35, CC.

3a. Umbilical view, $\times 300$.

3 b. Spiral view, $\times 300$.

Figure $4 \quad$ Globigerinelloides gottisi (Chevalier).

Sample 370-34-2, 73-75 cm.

Lateral view, $\times 600$.

Figure 5 Globigerinelloides caseyi (Bolli, Loeblich, and Tappan).

Sample $370-24-5,73-75 \mathrm{~cm}$.

5 a. Lateral view, $\times 150$.

$5 b$. Detail of the umbilical area, $\times 500$.

Figure $6 \quad$ Globigerinelloides bentonensis (Morrow).

Sample 370-24, CC.

Lateral view, $\times 150$.

Figure $7 \quad$ Globigerinelloides bentonensis (Morrow).

Sample 370-24, CC.

7a. Peripheral view, $\times 150$.

7b. Lateral view, $\times 150$.

Figure $8 \quad$ Globigerinelloides caseyi (Bolli, Loeblich, and Tappan).

Sample 367-21, CC.

Lateral view, $\times 150$.

Figure 9 Globigerinelloides caseyi (Bolli, Loeblich, and Tappan).

Sample 367-20, CC.

9a. Peripheral view, $\times 150$.

9 b. Lateral view, $\times 150$. 


\section{PLATE 3}
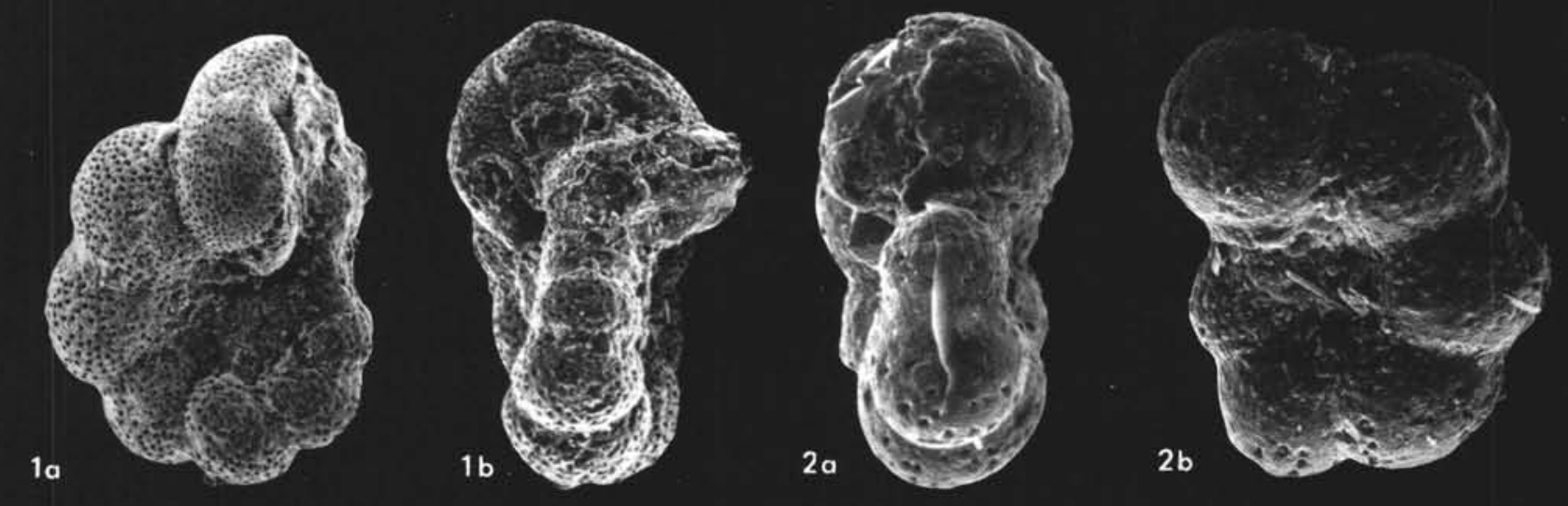

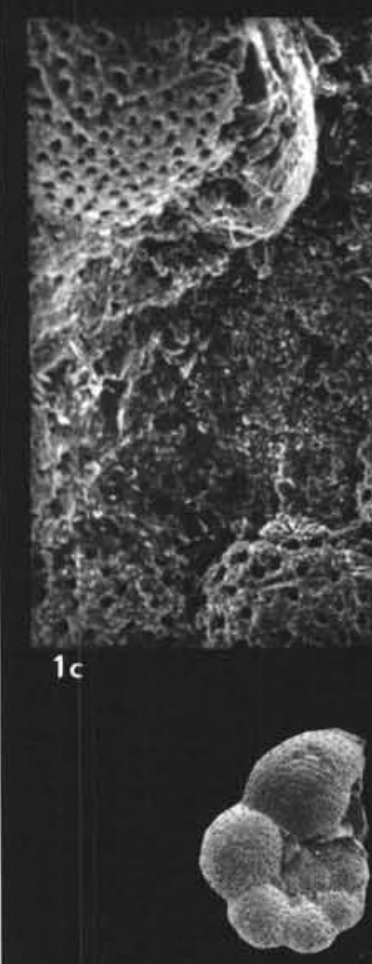

$5 a$

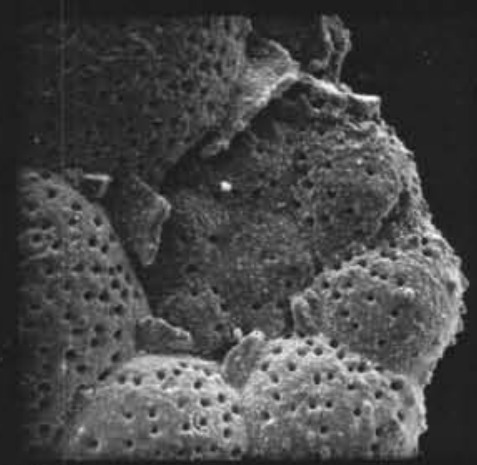

$5 b$

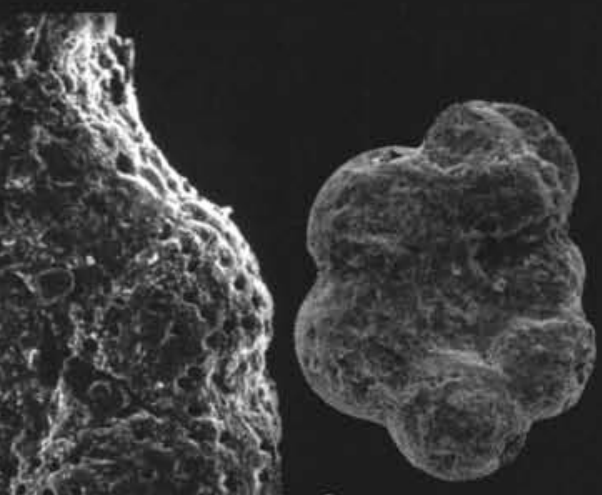

$3 a$
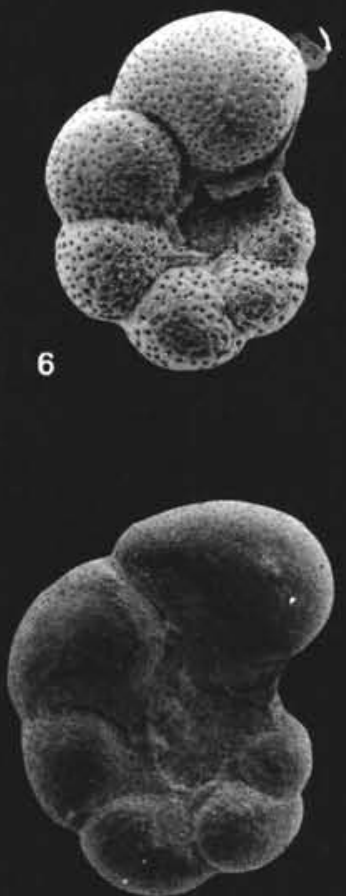

8
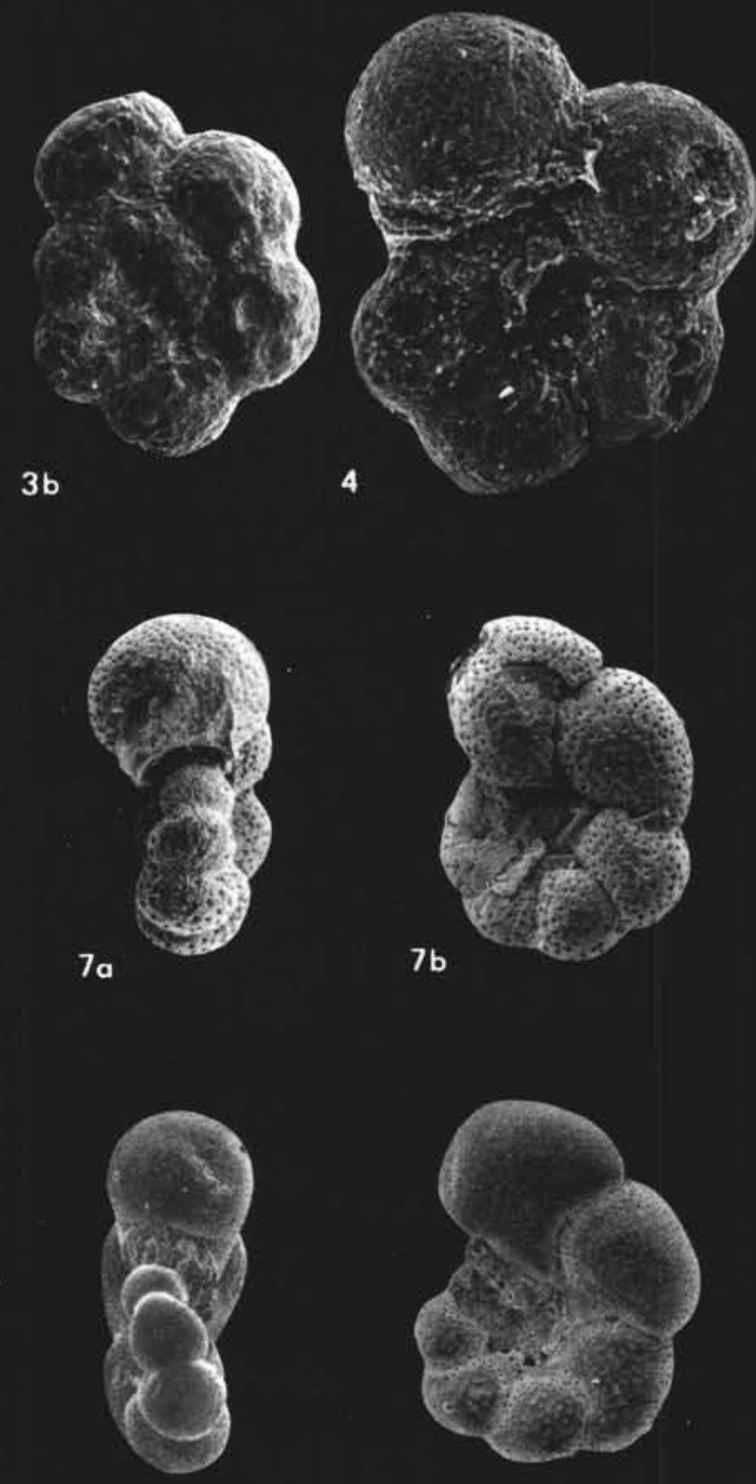

$9 a$

$9 b$ 


\section{PLATE 4}

Figures 1, 3 Praeglobotruncana delrioensis (Plummer). Sample 369A-43-1, 93-95 cm.

1. Spiral view, $\times 150$.

3a. Peripheral view, $\times 150$.

3 b. Umbilical view, $\times 150$.

Figure 2

Praeglobotruncana delrioensis (Plummer). Sample 369A-42-2, 83-85 cm.

$2 a$. Umbilical view, $\times 150$.

2b. Spiral view, $\times 150$.

Figure 4 Ticinella primula Luterbacher. Sample 369A-42-1, 73-75 cm.

Umbilical view, $\times 150$.

Figure 5 Ticinella primula Luterbacher. Sample 369A-43-3, 63-65 cm. Umbilical view, $\times 150$.

Figure 6 Ticinella primula Luterbacher. Sample 369A-43-3, 63-65 cm. 6 a. Peripheral view, $\times 150$. 6 b. Spiral view, $\times 150$.

Figure 7 Ticinella primula Luterbacher. Sample 369A-43-3, 63-65 cm. 7a. Peripheral view, $\times 150$. 7b. Umbilical view, $\times 150$.

Figure 8 Ticinella roberti (Gandolfi). Sample 369A-43-3, 63-65 cm. Spiral view, $\times 150$.

Figure 9 Ticinella roberti (Gandolfi). Sample 369A-43-3, 63-65 cm. 9a. Peripheral view, $\times 150$. 9b. Umbilical view, $\times 150$. 


\section{PLATE 4}
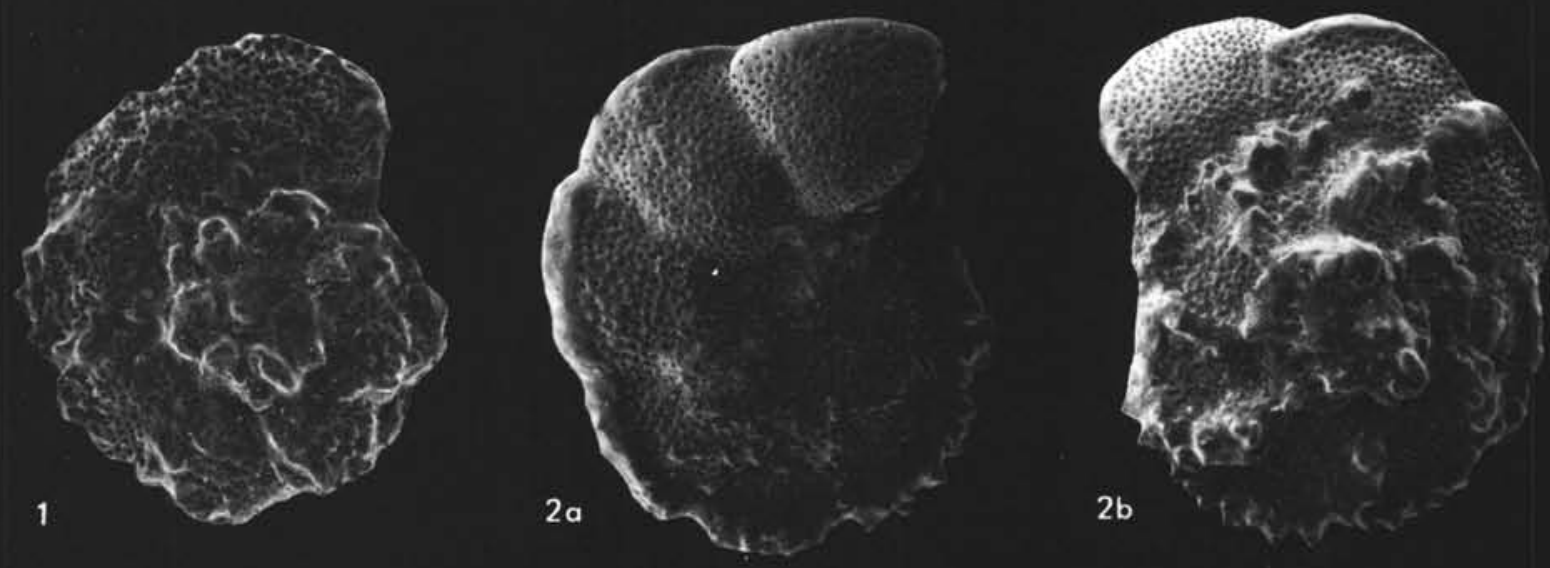

$2 b$
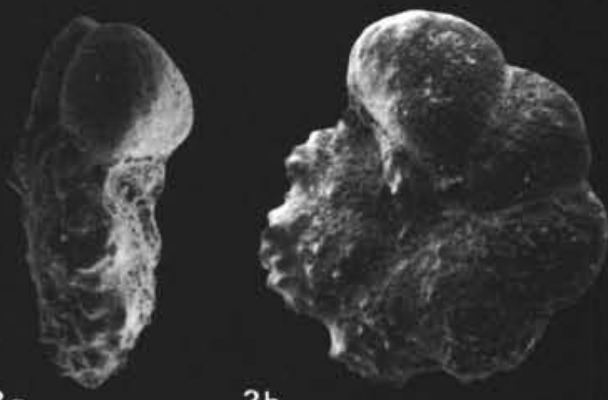

$3 b$

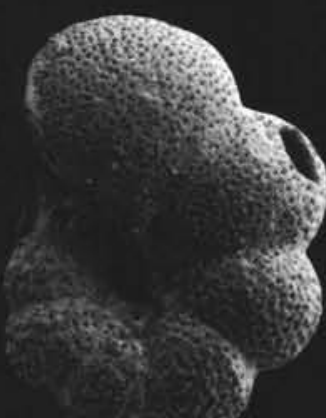

4

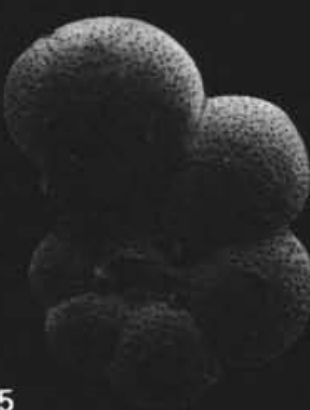

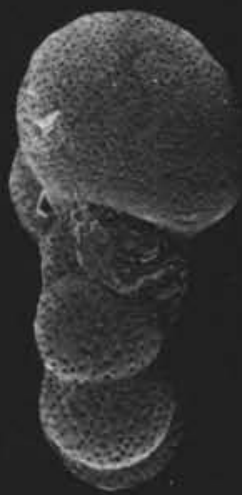

$6 a$

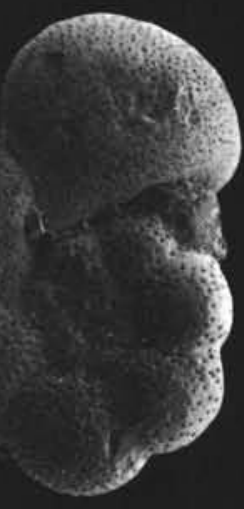

$6 b$

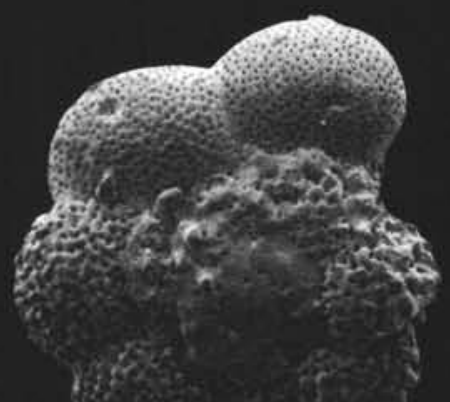

8

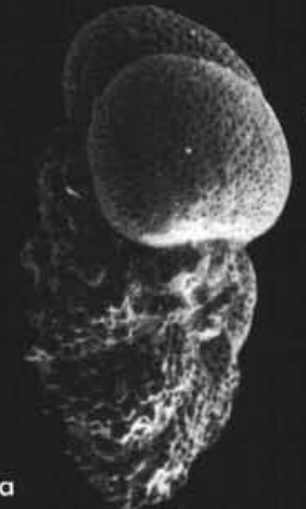

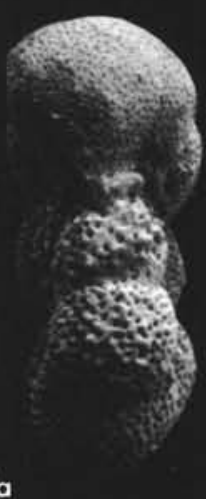

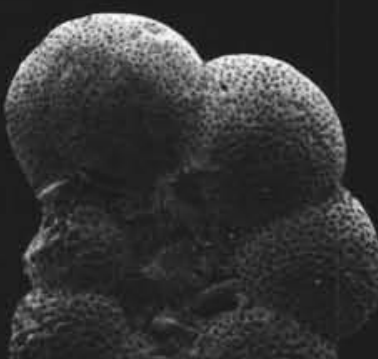

$7 b$

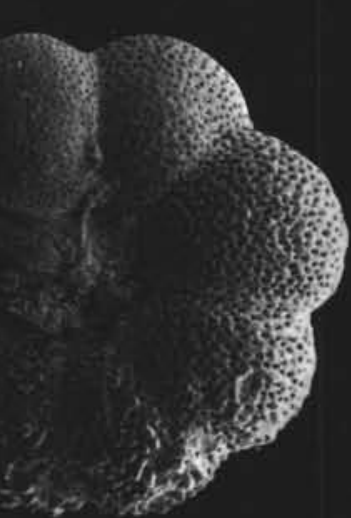




\section{PLATE 5}

Figure 1

Figure 2

Figure 3

Figure 4

Ticinella raynaudi aperta Sigal. Sample 369A-43-1, 93-95 cm. Spiral view, $\times 150$.

Ticinella raynaudi aperta Sigal. Sample 369A-43-1, 93-95 cm.

2a. Peripheral view, $\times 150$.

2b. Umbilical view, $\times 150$.

Ticinella raynaudi digitalis Sigal. Sample 369A-43-3, 63-65 cm.

Spiral view, $\times 150$.
Figure 5
Ticinella raynaudi digitalis Sigal. Sample 369A-43-3, 63-65 cm.
4a. Peripheral view, $\times 150$.
4b. Umbilical view, $\times 150$.
Ticinella breggiensis (Gandolfi), transitional to $T$. praeticinensis.
Sample 369A-43-1, 93-95 cm.
5 a. Lateral view, $\times 150$.
5 b. Peripheral view, $\times 150$.
5c. Lateral view, $\times 150$.

\section{PLATE 6}

Figures 1, 2 Rotalipors ticinensis (Gandolfi).

Sample 369A-42-1, 73-75 cm.

1. Spiral view, $\times 150$.

2a. Peripheral view, $\times 150$.

2b. Umbilical view, $\times 150$.

Figure 3 Rotalipora subticinensis (Gandolfi).

Sample 369A-42-2, 83-85 cm.

3 a. Umbilical view, $\times 150$.

3 b. Peripheral view, $\times 150$.

$3 c$. Spiral view, $\times 150$.

Figure $4 \quad$ Rotalipora ticinensis (Gandolfi), transitional to $R$. subticinensis.

Sample 369A-42-2, 83-85 cm.

4 a. Spiral view, $\times 150$.

4b. Peripheral view, $\times 150$.

4c. Umbilical view, $\times 150$.

(see page 562) 


\section{PLATE 5}
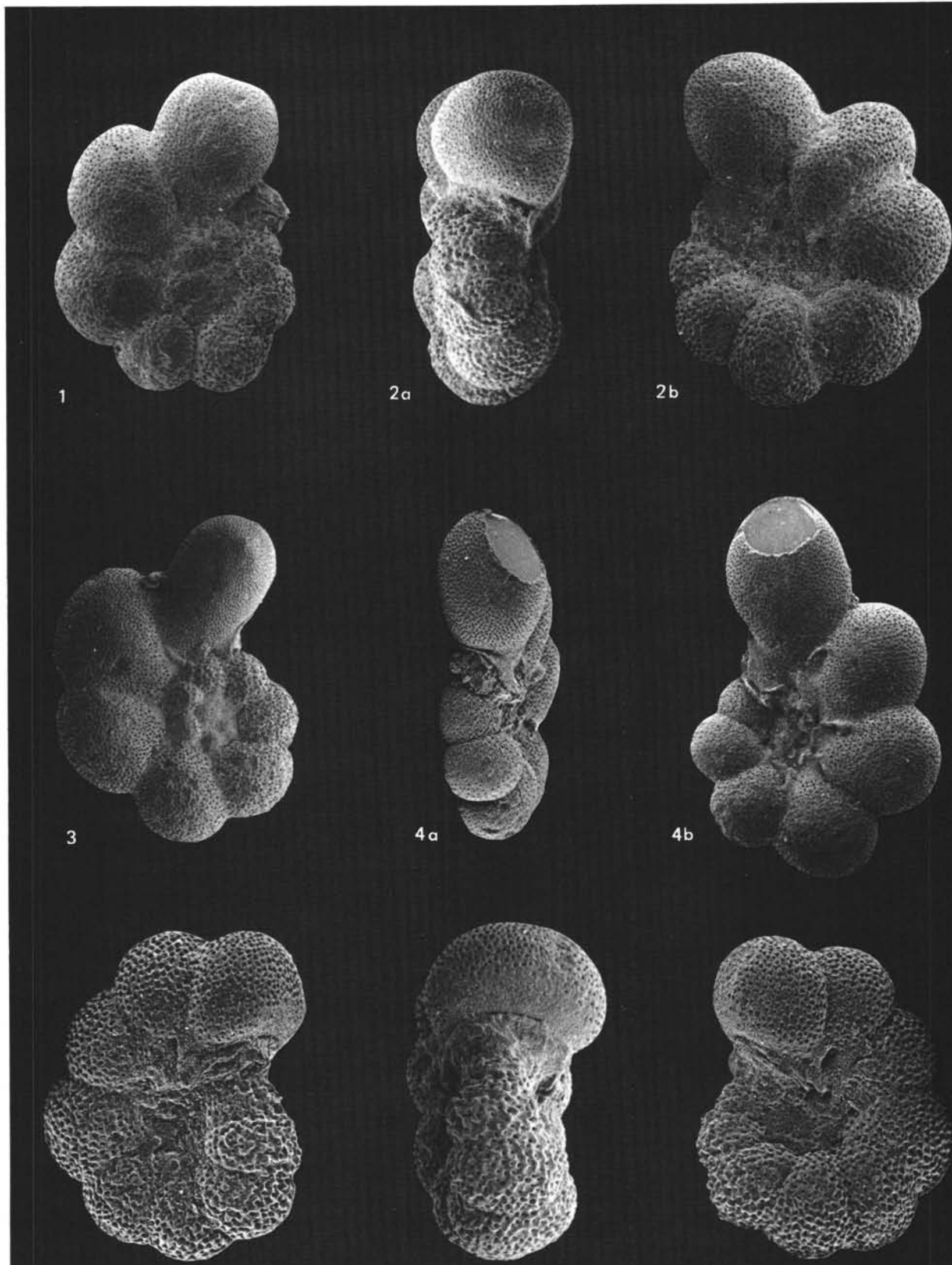

$5 a$

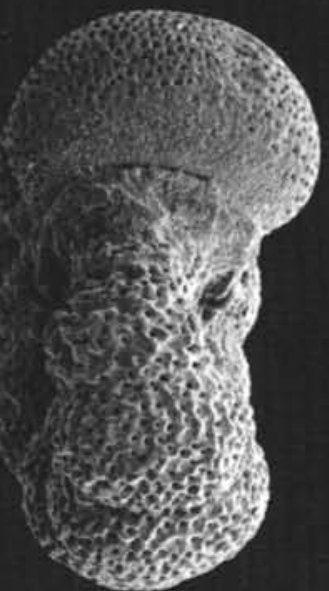

$5 b$

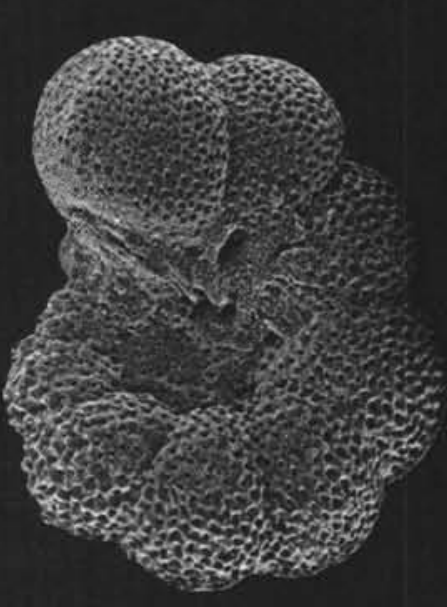

$5 c$ 


\section{PLATE 6}

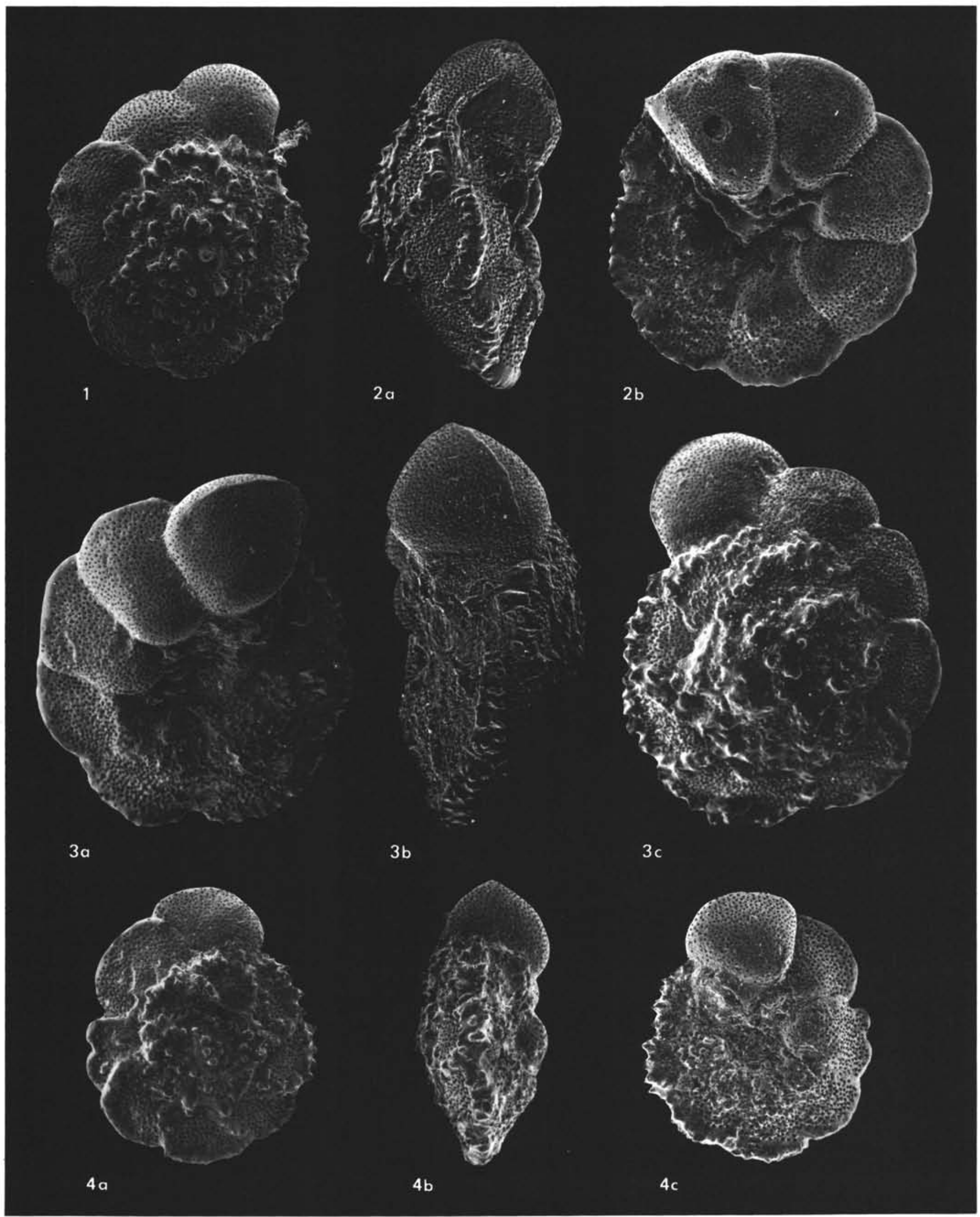




\section{PLATE 7}

Figure 1 Rotalipora apenninica (Renz).

Sample 370-24, CC.

1a. Spiral view, $\times 150$.

1b. Umbilical view, $\times 150$.

1c. Oblique view to the umbilical area, showing the supplementary apertures, covered by pustulose, nonporous prolongations of the chambers, $\times 250$.

Figures 2, 3 Clavihedbergella moremani (Cushman).

Sample 369A-42-2, 83-85 cm.

2. Spiral view, $\times 150$.

3. Spiral view, $\times 300$.

Figure $4 \quad$ Rotalipora apenninica (Renz).

Sample 370-24, CC.

4a. Spiral view, $\times 150$.

4b. Peripheral view, $\times 150$.

Figure $5 \quad$ Schackoina cf. cenomana (Schacko).

Sample 367-21-6, 110-112 cm.

Umbilical view, $\times 300$.

Figure 6 Schackoina cenomana (Schacko).

Sample 370-24-5, 73-75 cm.

Lateral view, $\times 150$.

Figure $7 \quad$ Schackoina cenomana (Schacko).

Sample 370-24, CC.

Spiral view, $\times 150$. 


\section{PLATE 7}

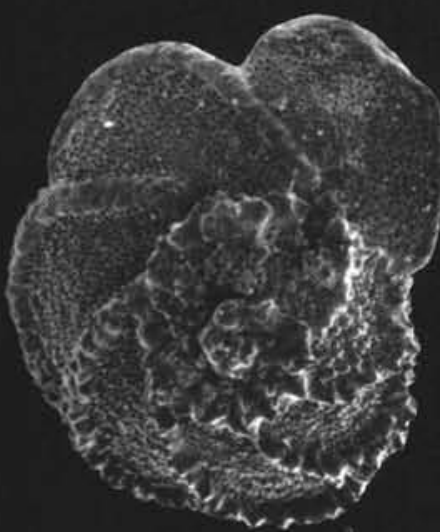

1a

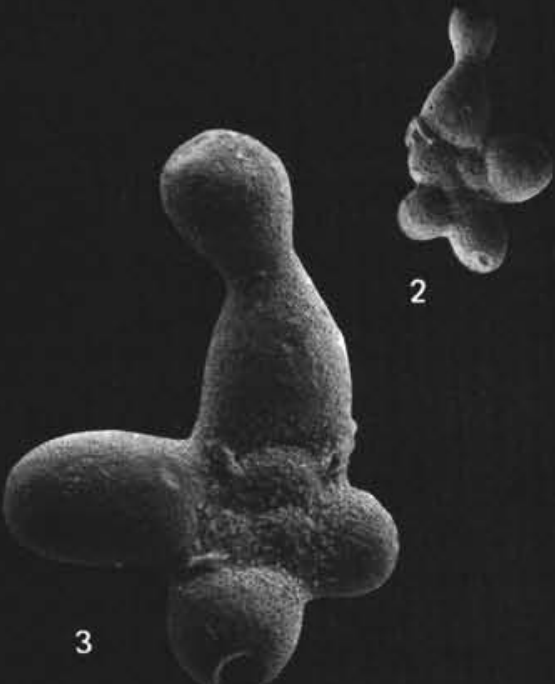

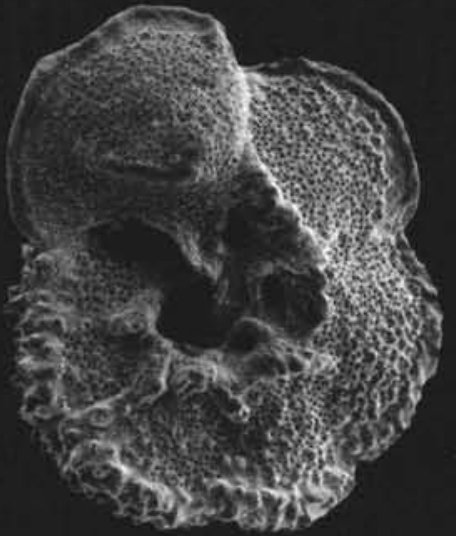

$1 \mathrm{~b}$

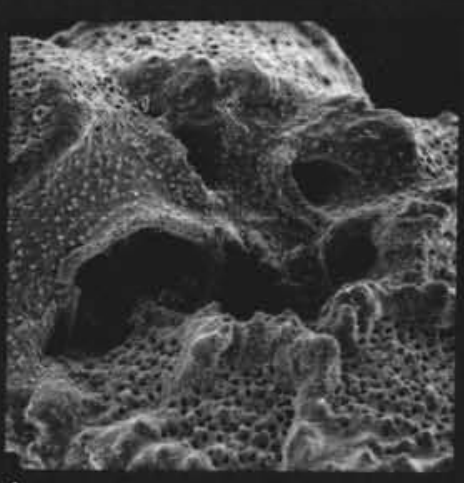
$1 c$
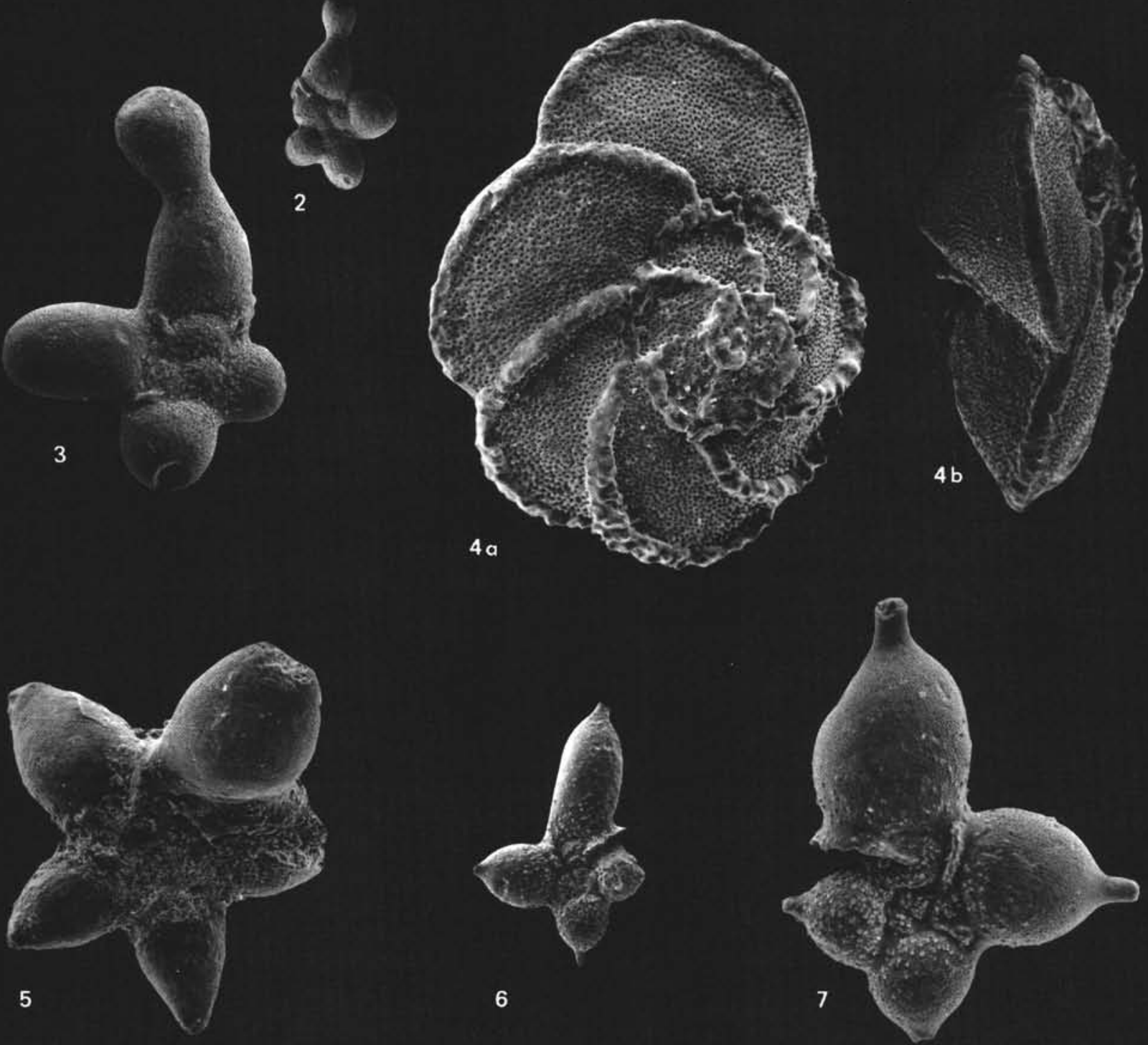